\title{
Prenatal Cocaine Reduces AMPA Receptor Synaptic Expression through Hyperphosphorylation of the Synaptic Anchoring Protein GRIP
}

\author{
Kalindi Bakshi, ${ }^{1,2,3}$ Serena Gennaro, ${ }^{1,5}$ Christopher Y. Chan, ${ }^{1,2}$ Mary Kosciuk, ${ }^{4}$ JingJing Liu,,${ }^{1,2}$ Andres Stucky, ${ }^{1,2}$ \\ Ekkehart Trenkner, ${ }^{2,3}$ Eitan Friedman, ${ }^{1,2}$ Robert G. Nagele, ${ }^{4}$ and Hoau-Yan Wang ${ }^{1,2}$ \\ ${ }^{1}$ Departments of Physiology and Pharmacology, Sophie Davis School of Biomedical Education, The City University of New York Medical School, New York, \\ New York 10031, ${ }^{2}$ Department of Biology and Neuroscience, Graduate School of The City University of New York, New York, New York 10061, ${ }^{3}$ College of \\ Staten Island, Institute for Basic Research Center for Developmental Neuroscience, The City University of New York, New York, New York $10314,{ }^{4}$ New \\ Jersey Institute for Successful Aging, University of Medicine and Dentistry of New Jersey-School of Osteopathic Medicine, Stratford, New Jersey 08084, and \\ ${ }^{5}$ Department of Neurological, Psychiatric, and Anesthesiological Sciences, University of Messina, 1-98122 Messina, Italy
}

Prenatal cocaine exposure produces sustained neurobehavioral and brain synaptic changes closely resembling those of animals with defective AMPA receptors (AMPARs). We hypothesized that prenatal cocaine exposure attenuates AMPAR signaling by interfering with AMPAR synaptic targeting. AMPAR function is governed by receptor cycling on and off the synaptic membrane through its interaction with glutamate receptor-interacting protein (GRIP), a PDZ domain protein that is regulated by reversible phosphorylation. Our results show that prenatal cocaine exposure markedly reduces AMPAR synaptic targeting and attenuates AMPAR-mediated synaptic long-term depression in the frontal cortex of 21-d-old rats. This cocaine effect is the result of reduced GRIP-AMPAR interaction caused by persistent phosphorylation of GRIP by protein kinase C (PKC) and Src tyrosine kinase. These data support the restoration of AMPAR activation via suppressing excessive PKC-mediated GRIP phosphorylation as a novel therapeutic approach to treat the neurobehavioral consequences of prenatal cocaine.

\section{Introduction}

Prenatal cocaine exposure produces long-lasting detrimental effects on cognitive function, especially evident in learning in both humans and animal models (Romano and Harvey, 1996; Morrow et al., 2006). Although the molecular mechanisms underlying these changes remain elusive, brain glutamate receptors that establish and stabilize synaptic connections during early development are intimately involved. In the adult brain, cocaine profoundly disrupts glutamatergic synaptic transmission and plasticity, in part by dysregulating AMPA receptors (AMPARs) (Wolf et al., 2004; Kauer and Malenka, 2007). A single intravenous cocaine injection to adult rats results in a higher ratio of AMPA- to NMDA-mediated activity changes in the ventral tegmental area and nucleus accumbens (NAc), further illustrating that AMPARs are highly sensitive to cocaine (Ungless et al., 2001; Saal et al., 2003). Extinction training after cocaine self-administration increases AMPAR expression in NAc of adult rats, and NAc overexpression of AMPAR facilitates extinction training (Sutton et al., 2003). Additionally, withdrawal from repeated cocaine expo-

\footnotetext{
Received Nov. 13, 2008; revised March 3, 2009; accepted April 1, 2009.

This work was supported by National Institute on Drug Abuse Public Service Grant MIDARP (E.F., H.-Y.W.) and The City University of New York collaborative grant (H.-Y.W.).

Correspondence should be addressed to Dr. Hoau-Yan Wang, Department of Physiology and Pharmacology, The City University of New York Medical School, H-210F, Harris Hall, 138th Street and Convent Avenue, New York, NY 10031. E-mail: hywang@sci.ccny.cuny.edu.

DOI:10.1523/JNEUROSCI.5485-08.2009

Copyright $\odot 2009$ Society for Neuroscience $\quad 0270-6474 / 09 / 296308-12 \$ 15.00 / 0$
}

sure upregulates excitatory synapses, whereas cocaine exposure during the withdrawal period initiates synaptic depression in the NAc (Thomas et al., 2001; Boudreau and Wolf, 2005; Boudreau et al., 2007; Kourrich et al., 2007; Conrad et al., 2008). These reports imply that AMPARs are pivotal regulators of cocaine-induced synaptic plasticity underlying altered cognitive processing including drug-seeking behaviors and predict that cocaine exposure during gestation may profoundly influence AMPARs.

AMPAR-mediated fast excitatory synaptic transmission in brain modulates neuronal development and maturation. AMPARs are composed of hetero-oligomeric combinations of GluR1-R4 subunits (Hollmann and Heinemann, 1994). The synaptic trafficking of AMPARs regulates activity-dependent synaptic plasticity underlying long-term potentiation and long-term depression (LTD) (Bredt and Nicoll, 2003). Although the density of GluR4-expressing AMPARs peaks during the first postnatal week but declines steadily to adult levels, GluR1/GluR2/GluR3containing AMPARs increase gradually and stabilizes at postnatal day 20 (Wenthold et al.,1996; Zhu et al., 2000). Synaptic activity drives membrane expression of GluR1-containing AMPARs, whereas GluR2/GluR3-containing AMPARs cycle constitutively on and off the synaptic membrane (Malinow et al., 2000; Shi et al., 2001) with their density regulated by synaptic activity (Liu and Cull-Candy, 2002). Accordingly, the subunit compositions and density of the membrane-associated AMPARs determine the basal synaptic strength and regulate synaptic plasticity (Turrigiano and Nelson, 2004). GluR2/GluR3 interact with synaptic 
a
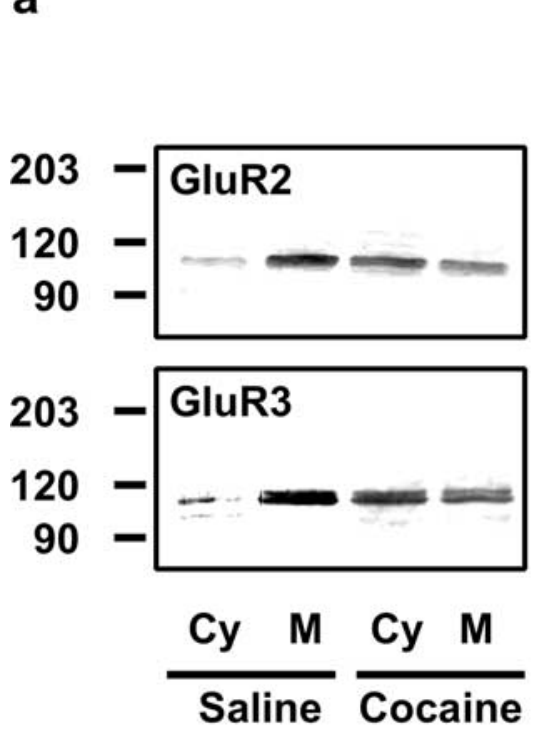

b

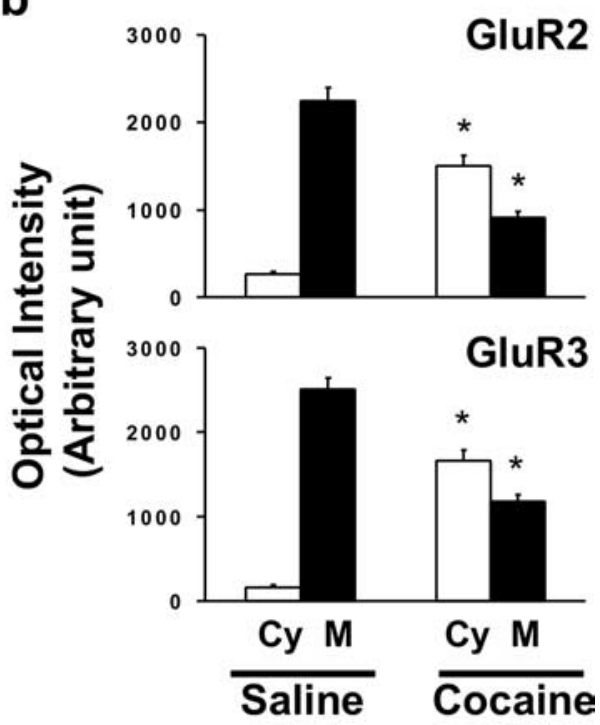

C

AMPA-GluR2
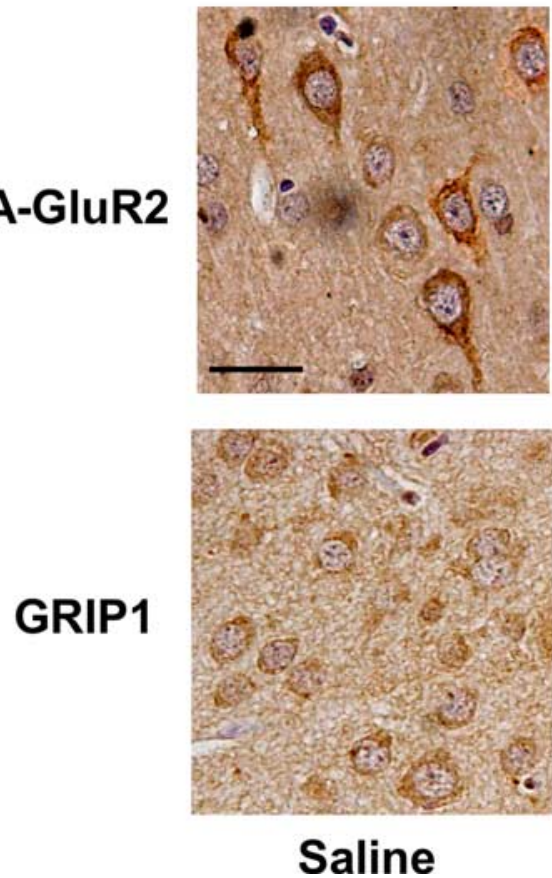
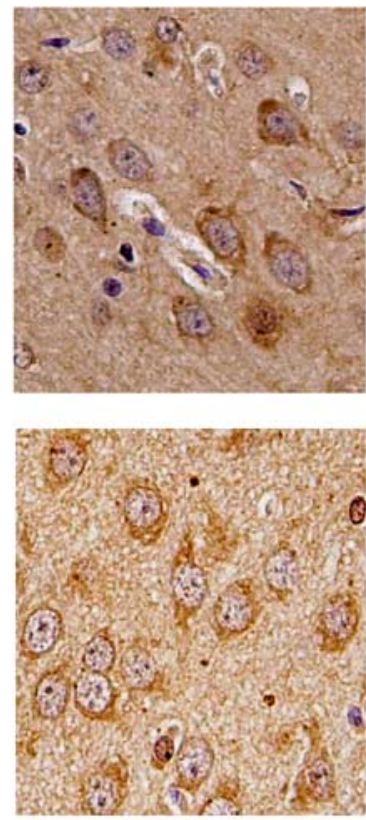

Cocaine

Figure 1. Synaptic expression of GluR2 and GluR3 is markedly reduced in the frontal cortex (FCX) of prenatal cocaine-exposed rats. $\boldsymbol{a}$, Western blot analysis of the GluR2 and GluR3 distribution in cytosol (Cy) and membrane (M) fractions of the synaptosomes prepared from FCX of P21 rats exposed to saline or cocaine during gestation. The blots were stripped and sequentially reprobed with anti-caspase-3 (1187 \pm 107 and $1210 \pm 99$ optical intensity in saline and cocaine, respectively) and GRIP1 (2509 \pm 132 and $2319 \pm 146$ optical intensity in saline and cocaine, respectively) to validate equal loading in cytosolic and membranous extracts. $\boldsymbol{b}$, The GluR2 or GluR3 bands were quantified individually. Data are presented as means \pm SEM of the optical intensity. $n=4$ for each group. ${ }^{*} p<0.01$ comparing the level of receptor in respective cytosol and membrane fractions. c, Immunohistochemical detection of GluR2 and GRIP1 in the frontal cortex of P21 prenatal saline- and cocaine-exposed rats. The representative sections show more GluR2 punctuates in membranes of saline-treated rats without discernible changes in GRIP1 levels. Scale bar, $50 \mu \mathrm{m}$. $n=4$ for each group.

scaffolding proteins: glutamate receptor-interacting protein (GRIP1/2) (Dong et al., 1997), AMPAR-binding protein (ABP) (Srivastava et al., 1998), and protein interacting with C kinase-1 (PICK1) (Xia et al., 1999). Although GRIP1/2 stabilizes GluR2/ GluR3 at the synaptic membrane, PICK1 promotes their internalization into cytoplasm (Kim et al., 2001). Hence, the level of interaction between AMPARs and postsynaptic density-95/Discs large/zona occludens-1 (PDZ)-containing proteins greatly impacts synaptic transmission, and any changes in these interactions may, therefore, alter synaptic activity.

In the present investigation, we test the hypothesis that reduced AMPAR density in synaptic membranes reduces AMPAR activation in prenatal cocaine-exposed brain. Our data identify a reduced GluR2/ 3-GRIP interaction as the primary mechanism through which prenatal cocaine exposure attenuates GluR2/GluR3 synaptic recruitment. This cocaine effect could delay brain maturation, resulting in cognitive impairments and vulnerability to neuropsychiatric disorders decades later.

\section{Materials and Methods}

Materials and chemicals. Soybean trypsin inhibitor, phenylmethylsulfonyl fluoride (PMSF), 2-mercaptoethanol, $\mathrm{NaF}, \mathrm{Na}_{2} \mathrm{VO}_{4}$, digitonin, protein phosphatase inhibitor I and II cocktails, recombinant $\gamma$ protein kinase $\mathrm{C}$ (PKC), alkaline phosphatase, phorbol 12-myristate, 13-acetate (PMA), anti-phosphoserine (P3430), and antiphosphothreonine (P3555) were purchased from Sigma. Leupeptin and aprotinin were from Peptide International. Recombinant Src, celestrine, and PP1 were from Calbiochem. Antibodies against GluR2 (SC-7610), GluR3 (SC-7613), phosphotyrosine (SC508), PKC $\alpha$ (SC-208), PKC $\beta$ (SC-209/210), PKC $\gamma$ (SC-211), PKC $\delta$ (SC-937), PKC $\varepsilon$ (SC214), GRIP1 (SC-17641), GRIP2 (SC-15477), phosphotyrosine (SC-508), caspase-3 (SC7272), N-ethylmaleimide-sensitive factor (NSF; SC-5828), PICK1 (SC-9541), and $\beta$-actin (SC-47778) were purchased from Santa Cruz Biotechnology. Antibodies against $\mathrm{pThr}{ }^{638 / 641} \mathrm{PKC} \alpha / \beta \mathrm{II} \quad$ (\#9375), pThr ${ }^{514} \mathrm{PKC} \gamma$ (\#9379), and $\mathrm{pThr}{ }^{410} \mathrm{PKC/}$

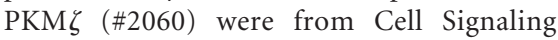
Technology. Seize-X immunoprecipitation kit, antigen elution buffer, and West pico chemiluminescent reagents were purchased from Pierce-Endogen. Bradford reagent, SDS-PAGE reagents, and prestained molecular weight markers were purchased from BioRad. Cutoff filters $(10 \mathrm{kDa})$ were obtained from Cole-Palmer. ABP (AB5569) and $\beta$-tubulin (MAB3408) were from Millipore Bioscience Research Reagents. Target buffer was purchased from Dako. Avidin-peroxidase-labeled biotin complex (ABC) was from Vector Laboratories. 3-3-diaminobenzidine-4 $\mathrm{HCl}$ (DAB)/ $\mathrm{H}_{2} \mathrm{O}_{2}$ was from Biomeda.

Animal treatment. Pathogen-free, 10-weekold male and female Sprague Dawley rats weighing $\sim 200-215 \mathrm{~g}$ (Taconic) were housed individually in a $12 \mathrm{~h}$ light/dark cycle with ad libitum access to food and water. All animal procedures were in compliance with the National Institutes of Health Guide for the Care and Use of Laboratory Animals and were approved by the City College of New York Animal Care and Use Committee. A pair of 10-week-old male and female rats was placed in a cage overnight. In each experiment set, we used four mating pairs. The presence of a sperm-positive vaginal plug indicated gestational day (GD) 
0 . The pregnant female rats were housed individually without disturbance other than the daily injection with cocaine or saline. On GD 1, pregnant dams were assigned to receive daily subcutaneous injections from GD 1-21 of either cocaine $\mathrm{HCl}, 30 \mathrm{mg} / \mathrm{kg}$ in $0.9 \%$ saline or saline, $2 \mathrm{ml} / \mathrm{kg}$. The animals were injected daily between 9:00-10:00 A.M. After each injection, these pregnant rats were observed for $1 \mathrm{~h}$ and behavioral abnormalities recorded. There were apparent increases in locomotor activity in cocaine-treated rats. To minimize skin lesions and tissue necrosis in the cocaine-injected rats, the injection sites were rotated over different sites on the back. There were no discernible differences in litter size (between 7-13 pups) and body weight of the pups at $21 \mathrm{~d}$ of age $(48.9 \pm$ 2.5 and $50.7 \pm 2.8 \mathrm{~g}$ for cocaine and saline, respectively; $n=40$ each) and gender distribution (23 males/17 females and 19 males/21 females for cocaine and saline groups, respectively). There was also no correlation between the magnitudes of tissue necrosis induced by subcutaneous cocaine injections and litter size or body weight of the pups. There were no obvious changes in rearing behaviors. Importantly, the dose of cocaine used in this study did not induce seizure or fatality.

In a separate experiment series, confirmed pregnant dams were assigned to receive daily intraperitoneal injections from GD 8-20 of either cocaine $\mathrm{HCl}, 30 \mathrm{mg} / \mathrm{kg}$ in $0.9 \%$ saline or saline, $2 \mathrm{ml} / \mathrm{kg}$. The animals were also injected daily at 9:00-10:00 A.M.

The progenies were group-housed with their mother until being killed at $21 \mathrm{~d}$ of age postnatal day 21 (P21)]. Food and water were available ad libitum. They were subjected to the minimum handling associated with routine animal husbandry. Since we did not find gender differences in our previous studies conducted in rabbit and rats (H. Y. Wang et al., 1995; Jones et al., 2000; Yablonsky-Alter et al., 2005), both sexes from separate litters were used in these experiments. Pups were killed by rapid decapitation, the brain was removed immediately, and frontal cortices were dissected on ice.

Preparation of synaptosomes and fractionation. Synaptosomes (P2 fraction) were prepared from frontal cortices as described previously with few modifications (Wang et al., 1994, 1999). To further purify synaptosomal factions, the synaptosome-enriched P2 fraction was washed twice in $5 \mathrm{ml}$ of icecold Kreb's-Ringer's solution (25 mм HEPES, pH 7.4; 118 mм NaCl, 4.8 $\mathrm{mm} \mathrm{KCl}, 25 \mathrm{~mm} \mathrm{NaHCO}, 1.3 \mathrm{~mm} \mathrm{CaCl}, 1.2 \mathrm{~mm} \mathrm{MgSO}_{4}, 1.2 \mathrm{~mm}$ $\mathrm{KH}_{2} \mathrm{PO}_{4}, 10 \mathrm{~mm}$ glucose, $100 \mu \mathrm{M}$ ascorbic acid, $50 \mu \mathrm{g} / \mathrm{ml}$ leupeptin, 10 $\mu \mathrm{g} / \mathrm{ml}$ aprotinin, $2 \mu \mathrm{g} / \mathrm{ml}$ soybean trypsin inhibitor, $0.04 \mathrm{~mm}$ PMSF, 0.1 $\mathrm{mm} 2$ 2-mercaptoethanol, $10 \mathrm{~mm} \mathrm{NaF}, 1 \mathrm{mM} \mathrm{Na}_{2} \mathrm{VO}_{4}$, and $0.5 \mu \mathrm{l} / \mathrm{ml}$ protein phosphatase inhibitor I and II cocktails). To obtain cytosolic and membranous fractions of the synaptosomes, the washed synaptosomes were sonicated for $10 \mathrm{~s}$ on ice in $0.5 \mathrm{ml}$ hypotonic homogenization solution (25 mM HEPES, pH 7.4; $120 \mathrm{~mm} \mathrm{NaCl}, 4.8 \mathrm{~mm} \mathrm{KCl}, 25 \mathrm{~mm} \mathrm{NaHCO}_{3}$, $1.3 \mathrm{~mm} \mathrm{CaCl}_{2}, 1.2 \mathrm{~mm} \mathrm{MgSO}_{4}, 1.2 \mathrm{~mm} \mathrm{KH}_{2} \mathrm{PO}_{4}, 10 \mathrm{~mm}$ glucose, $100 \mu \mathrm{M}$ ascorbic acid, $50 \mu \mathrm{g} / \mathrm{ml}$ leupeptin, $10 \mu \mathrm{g} / \mathrm{ml}$ aprotinin, $2 \mu \mathrm{g} / \mathrm{ml}$ soybean trypsin inhibitor, $0.04 \mathrm{~mm}$ PMSF, and $0.1 \mathrm{~mm} 2$-mercaptoethanol, $10 \mathrm{~mm}$ $\mathrm{NaF}, 1 \mathrm{mM} \mathrm{Na}_{2} \mathrm{VO}_{4}$, and $0.5 \mu \mathrm{l} / \mathrm{ml}$ protein phosphatase inhibitor I and II cocktails). Samples were centrifuged at $50,000 \times g$ for $30 \mathrm{~min}$. The resultant supernatant was reserved as the cytosolic fraction, and the synaptic membrane pellet was resuspended in $0.5 \mathrm{ml}$ of hypotonic solution. Protein concentrations of the synaptic membranes were determined us-
Cocaine
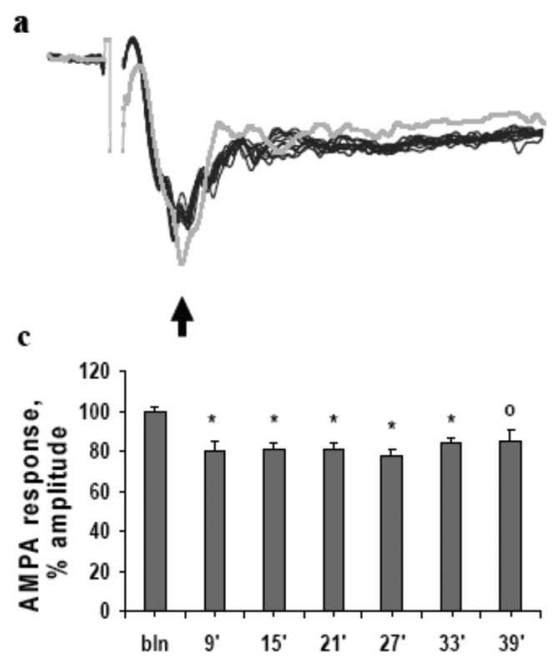

Minutes after low-frequency stimulation
Saline

b

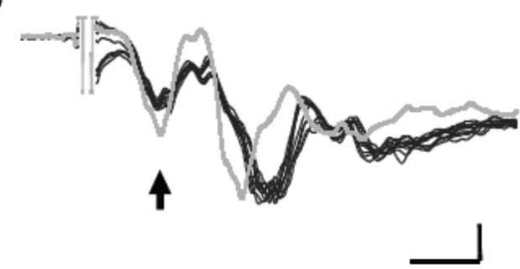

d

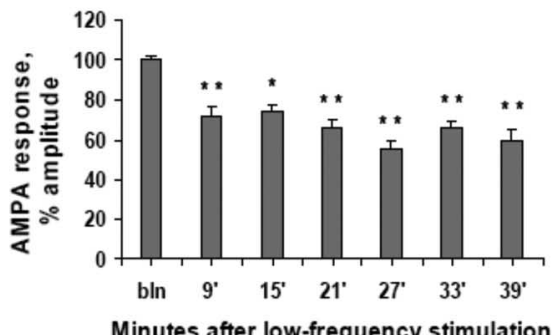

Figure 2. LTD in medial prefrontal cortical slices from prenatal cocaine- and saline-exposed rats. $\boldsymbol{a}$, Field potential recording of in (arrowhead). $\boldsymbol{d}$, Similar bar graph representing the relative amplitudes of post-LFS responses in $\boldsymbol{b}$ measured at the first negative 作 course of prenatal cocaine- versus saline-exposed brain were compared using two-factor ANOVA $(p<0.01)$. Calibration: 5 ms, $0.2 \mathrm{mV} . n=4$ for each group.e, A typical field potential response evoked in Layer III of a rat $\mathrm{mPFC}$ slice by off-radius electrical pulse stimulation of Layer II showing negative waves labeled $a$, an AMPA receptor-mediated response component identified through its blockade by CNQX; and $b$, NMDA receptor-mediated components identified using APV, a selective NMDA blocker. The early part of the NMDA receptor response was sensitive to R0 25-6981, a blocker for the NR2B subunit-containing NMDA receptor, and it overlapped with the later part but not the peak of the AMPA receptor response. Calibration: $0.2 \mathrm{mV}, 50 \mathrm{~ms}$.

Table 1. Comparison of the number and percentage of tested animals showing LTD ( $>10 \%$ reduction from baseline) from prenatal saline- and prenatal cocaineexposed rats

\begin{tabular}{lll}
\hline & Saline $(n=15)$ & Cocaine $(n=16)$ \\
\hline Number showing LTD & 11 & 7 \\
$\%$ showing LTD & $73 \%$ & $43 \%$ \\
Decrease $>20 \%$ & 8 & 2 \\
\hline
\end{tabular}

Shown in the last row are the number of animals exhibiting a $>20 \%$ LTD. $n$, Number of slices recorded.

ing the Bradford method before solubilization by boiling for $5 \mathrm{~min}$ in $6 \times$ SDS-PAGE sample preparation buffer.

Immunoaffinity purification of native GluR2, GluR3, GRIP1, and GRIP2. To isolate native GluR2, GluR3, GRIP1, and GRIP2, frontal cortices of P21 prenatal cocaine- or saline-exposed rats were homogenized in hypotonic homogenization solution as described above. The obtained homogenates were solubilized using $0.5 \%$ digitonin, $0.2 \%$ sodium cholate, $0.5 \% \mathrm{NP}-40$, and $0.2 \%$ SDS in the presence of cocktails of protease and protein phosphatase inhibitors for $20 \mathrm{~min}$ at $25^{\circ} \mathrm{C}$ followed by 
Table 2. Mean amplitudes of the AMPA receptor component of the basal responses to a range of stimulus intensities in prenatal saline- and cocaine-exposed male rats

\begin{tabular}{|c|c|c|c|c|c|c|c|}
\hline \multirow{2}{*}{$\begin{array}{l}\text { Stimulation } \\
\text { intensity } \\
\text { (a.u.) }\end{array}$} & \multicolumn{3}{|l|}{ Saline } & \multicolumn{4}{|l|}{ Cocaine } \\
\hline & $\begin{array}{l}\text { Mean response } \\
\text { amplitude (mV) }\end{array}$ & SEM & & $\begin{array}{l}\text { Mean response } \\
\text { amplitude (mV) }\end{array}$ & SEM & & \\
\hline 1 & 0.09 & 0.02 & $n=21$ & 0.13 & 0.03 & $n=15$ & NS \\
\hline 1.5 & 0.62 & 0.13 & $n=15$ & 0.52 & 0.06 & $n=8$ & NS \\
\hline 2 & 0.71 & 0.11 & $n=21$ & 0.69 & 0.08 & $n=15$ & NS \\
\hline 3 & 0.93 & 0.13 & $n=21$ & 0.91 & 0.09 & $n=15$ & NS \\
\hline
\end{tabular}

Student's two-tailed $t$ test shows no significant (NS) difference between the two groups for any stimulus intensity in the range tested. a.u., Arbitrary units.

$60 \mathrm{~min}$ at $4^{\circ} \mathrm{C}$ with end-over-end constant shaking. After centrifugation to remove insoluble debris, the obtained brain lysate was diluted fivefold, and GRIP1, GluR2, and GluR3 were individually purified using immunoaffinity columns (Seize-X immunoprecipitation kit) with covalently immobilized antibodies directed against GluR2, GluR3, GRIP1, and GRIP2, according to manufacturer's instructions. GluR2, GluR3, GRIP1, and GRIP2 were each eluted twice with $90 \mu \mathrm{l}$ antigen elution buffer. The resultant eluates were neutralized immediately with $20 \mu \mathrm{l} 1.5 \mathrm{M}$ Tris, $\mathrm{pH}$ 8.8 , and concentrated to $100 \mu \mathrm{l}$ by passing through a $10 \mathrm{kDa}$ cutoff filter. Protein concentrations were determined using the Bradford method. The purity of each protein was validated by Western blotting. In each case, the purified protein yielded a single protein band with apparent molecular weight identical to that found using rat brain lysate.

In vitro determination of GluR2-GRIP1 interaction and immunoprecipitation. To control the GRIP1 phosphorylation state, native GRIP1 proteins $(10 \mu \mathrm{g})$ purified from frontal cortices of $\mathrm{P} 21$ prenatal saline- and cocaine-exposed rats were incubated with $100 \mu \mathrm{g} / \mathrm{ml}$ alkaline phosphatase in Tris, $\mathrm{pH} 8.0,130 \mathrm{~mm} \mathrm{NaCl}$, and protease inhibitors at $30^{\circ} \mathrm{C}$ for 20 min (total incubation volume $100 \mu \mathrm{l}$ ). The phosphatase activity was terminated by $10 \mathrm{~mm} \mathrm{NaF} / 1 \mathrm{~mm} \mathrm{Na}_{3} \mathrm{VO}_{4}$, and specific PKC- and srcmediated phosphorylation was induced by incubation with $0.5 \mu \mathrm{g} / \mathrm{ml}$ recombinant $\gamma \mathrm{PKC}, 20 \mu \mathrm{g}$ phosphotidylserine, and $100 \mathrm{nM}$ PMA or 10 $\mu \mathrm{g} / \mathrm{ml}$ recombinant Src in the presence of $30 \mu \mathrm{M}$ ATP in Kreb's-Ringer's at $30^{\circ} \mathrm{C}$ for $10 \mathrm{~min}$ (total incubation volume $125 \mu \mathrm{l}$ ). The actions of PKC and Src were terminated by addition of $1 \mu \mathrm{M}$ celestrine and PP1, respectively. One-half of the GRIP1 solution (containing $5 \mu \mathrm{g}$ ) was immediately solubilized by adding $6 \times$ SDS-PAGE sample preparation buffer and boiled for $5 \mathrm{~min}$ for analysis of phosphoserine and phosphothreonine and phosphotyrosine levels by Western blotting. To determine the influence of GRIP1 phosphorylation state on the interaction between GRIP1 and GluR2, purified brain GluR2 $(5 \mu \mathrm{g})$ from gestational saline- and cocaine-exposed rats were individually added to $5 \mu \mathrm{g}$ of GRIP1 with different phosphorylation states and incubated in $100 \mu \mathrm{g} / \mathrm{ml}$ brain phospholipids, $1 \%$ BSA-containing Kreb's-Ringer's at $30^{\circ} \mathrm{C}$ for 30 min with constant end-over-end shaking. The GRIP1-associated GluR2 was isolated along with GRIP1 by $20 \mu \mathrm{l}$ immobilized anti-GRIP1-conjugated protein $\mathrm{A}$-agarose beads and measured using Western blot with antiGluR2. The obtained blots were screened for phosphoserine first (antiphosphoserine), stripped, and reprobed twice sequentially with antiphosphotyrosine and anti-GRIP1. The signals were detected using a chemiluminescent method and visualized by exposure to $\mathrm{x}$-ray film.

Western blotting. To determine cellular distribution or the interaction between GluR2 or GluR3 and GRIP1, cytosolic and membranous fractions of frontal cortices or anti-GRIP1 immunoprecipitates were boiled for $5 \mathrm{~min}$ in $100 \mu \mathrm{l}$ SDS-PAGE sample buffer (62.5 mM Tris-HCl, pH 6.8; $10 \%$ glycerol, $2 \%$ SDS; $5 \%$ 2-mercaptoethanol, $0.1 \%$ bromophenol blue) and then size fractionated on 7.5 or 10\% SDS-PAGE based on the molecular mass of the protein. Proteins were electrophoretically transferred to nitrocellulose membrane, and Western blotting was performed with antibodies for GluR2, GluR3, phosphotyrosine, phosphoserine, phosphothreonine, $\mathrm{PKC} \alpha$, PKC $\beta$, PKC $\gamma, \mathrm{PKC} \delta, \operatorname{PKC} \varepsilon, \mathrm{pThr}^{638 / 641} \mathrm{PKC} \alpha /$ $\beta \mathrm{II}, \mathrm{pThr}{ }^{514} \mathrm{PKC} \gamma$, and $\mathrm{pThr}{ }^{410} \mathrm{PKC} / \mathrm{PKM} \zeta$. The blots were stripped and reprobed with anti-GRIP1 or caspase- 3 to assess the level of sample loading.

To determine the expression level of GluR2, GluR3, GRIP1, GRIP2, protein extracts of the synaptosome-enriched P2 fractions $(50 \mu \mathrm{g})$ were size fractionated on $7.5 \%$ SDS-PAGE, and Western blotting was performed using antibodies against GluR2, GluR3, p-GluR2/3(Ser ${ }^{880}$ / Ser ${ }^{891}$ ), GRIP1, GRIP2, ABP, NSF, and PICK1. In some cases, the blots were stripped and reprobed with anti- $\beta$-actin, $\beta$-tubulin, and GRIP1.

Immunoreactivity was detected by reacting with chemiluminescent reagents for exactly 5 min and visualized by immediately exposing to $\mathrm{x}$-ray film for 10-30 s. Specific protein bands were quantified by densitometric scanning (GS-800 calibrated densitometer; Bio-Rad Laboratories).

Electrophysiological studies. To elucidate the impact of prenatal cocaine exposure on AMPAR function during brain maturation, electrophysiological recordings that focus on AMPAR function were performed in $400-\mu \mathrm{m}$-thick medial prefrontal cortical slices (mPFC) from P21-P25 prenatal cocaine- or saline-exposed (and some treatment naive) rats. This procedure was performed as described previously (Otani et al., 1998 ) with modifications to determine AMPAR-mediated LTD.

Brain slice preparation. Rats were decapitated under anesthesia (60 $\mathrm{mg} / \mathrm{kg}$ pentobarbital sodium) and the craniums quickly opened. Brains were removed and placed in ice-cold artificial CSF (ACSF) saturated with $5 \% \mathrm{CO}_{2}$ and $95 \% \mathrm{O}_{2}$ for $2 \mathrm{~min}$, then blocked and sectioned into $400 \mu \mathrm{m}$ coronal slices using a Vibratome (TPI). Slices were incubated at room temperature $\left(\sim 25^{\circ} \mathrm{C}\right)$ in ACSF bubbled with the $\mathrm{CO}_{2} / \mathrm{O}_{2}$ gas mixture for $2 \mathrm{~h}$ before recording. ACSF contained $138 \mathrm{~mm} \mathrm{NaCl}, 3.0 \mathrm{~mm} \mathrm{KCl}, 1.2 \mathrm{~mm}$ $\mathrm{NaH}_{2} \mathrm{PO}_{4}, 20.25 \mathrm{~mm} \mathrm{NaHCO}, 2 \mathrm{~mm} \mathrm{CaCl}_{2}, 1.3 \mathrm{~mm} \mathrm{MgCl}_{2}$, and $25 \mathrm{~mm}$ dextrose.

Electrophysiological recording. All brain slices were recorded in a submersion-type recording chamber (Warner Instruments) superfused $(2 \mathrm{ml} / \mathrm{min}$ ) with ACSF containing $80 \mu \mathrm{M}$ picrotoxin at room temperature $\left(22-25^{\circ} \mathrm{C}\right)$. Evoked field potential in layer III of rat prefrontal cortical slices were recorded through a glass micropipette (with a $4-5 \mu \mathrm{m}$ tip) filled with $1 \mathrm{~m} \mathrm{Na}$ acetate placed in the prelimbic area $300 \mu \mathrm{m}$ from the pia. To evoke baseline responses, single electrical pulses $(0.1 \mathrm{~ms}, 0.1 \mathrm{~Hz}$, at $2 \times$ threshold strength) were delivered through a concentric bipolar electrode (Frederick Haer Corporation) placed on layer I/II $100 \mu \mathrm{m}$ lateral to the radial axis of the recording location to favor activation of axons from nearby columns (i.e., by across-column stimulation). Voltage responses were led to a d.c. amplifier (Axoclamp 2a) and digitized by a 16-bit analog-to-digital converter (Measurement Computing) operated through data-acquisition software (Snapmaster 3.5; Hem Corp). The responses were averaged over four frames to improve signal-to-noise ratio, then subsequently analyzed in real time.

LTD was elicited by a single train of low-frequency stimulation (LFS; $2.4 \mathrm{~Hz}$ of triplets at $500 \mathrm{~Hz}$, for $10 \mathrm{~min}$ ) delivered to the same location at the same strength as for baseline responses. After LFS, single-test responses were evoked for $40 \mathrm{~min}$ by the same way as for baseline responses and plotted against time to reveal any persistent depression from the baseline amplitude.

Immunohistochemistry. Immunohistochemical analyses were performed using antibodies directed against GluR2, GluR3, GRIP1, and GRIP2 and were performed on paraffin-embedded tissues as described previously (Nagele et al., 2002). Briefly, after removal of paraffin with xylene and rehydration through a graded series of decreasing concentrations of ethanol, protein antigenicity was enhanced by microwaving sections in target buffer for $2 \mathrm{~min}$. After a $30 \mathrm{~min}$ incubation in $0.3 \% \mathrm{H}_{2} \mathrm{O}_{2}$, sections were treated for $30 \mathrm{~min}$ in normal blocking serum and then incubated with primary antibodies at appropriate dilutions for $1 \mathrm{~h}$ at room temperature. After a thorough rinse in PBS, a secondary biotinlabeled antibody was applied for $30 \mathrm{~min}$. Immunoreactions were treated with the $A B C$ and visualized by treatment of sections with $\mathrm{DAB} / \mathrm{H}_{2} \mathrm{O}_{2}$. Sections were lightly counterstained with hematoxylin, dehydrated through a graded series of increasing concentrations of ethanols, cleared in xylene, and mounted in Permount. Controls consisted of comparable sections treated with nonimmune serum, preabsorbed antibody, or omission of the primary antibody. Specimens were examined and pho- 
tographed with a Nikon FXA microscope, and digital images were recorded using a Nikon DXM1200F digital camera and processed using Image Pro Plus (Phase 3 Imaging) imaging software.

Data analysis and statistical evaluation. Statistical differences between cocaine and saline groups were assessed using the two-tailed Student's $t$ test. Differences between in vitro doseresponse relations were analyzed by ANOVA followed by Newman-Keuls multiple comparisons.

\section{Results}

Prenatal cocaine reduces the synaptic targeting of GluR2 and GluR3 subunits The effect of prenatal cocaine exposure during the entire gestation on the distribution of GluR2- and GluR3-containing AMPARs was determined in synaptosomes prepared from the frontal cortices of 21-d-old (P21) rats prenatally exposed to cocaine or saline (control). We measured the relative levels of GluR2 and GluR3 in the cytosol and synaptic membranes of these synaptosomes. Although the majority of GluR2 $(89.7 \pm 6.2 \%)$ and GluR3 (94.1 $\pm 5.1 \%$ ) are located in synaptic membrane of saline-treated brains, prenatal cocaine exposure dramatically reduced synaptic membrane-associated GluR2 and GluR3 levels, concurrent with corresponding increases in the abundance of cytosolic GluR2 $(62.3 \pm 5.1 \%$ of the overall GluR2 expression levels in synaptosomes) and GluR3 (58.6 $\pm 4.5 \%$ of the overall GluR3 expression levels in synaptosomes) (Fig. 1a,b). The higher level of membrane-localized GluR2 in prenatal saline-treated brains was consistent with the immunohistochemical results that show more GluR2-immunoreactive puncta on membranes (Fig. 1c). Similarly, significant retention of GluR2 and GluR3 in the cytosol was also observed in synaptosomes of frontal cortices from 21-d-old rats exposed to cocaine during gestation days 8-20 (supplemental Fig. 1, available at www.jneurosci.org as supplemental material).

Since GluR1-containing AMPARs and the constitutive cycling pool of GluR2and GluR3-containing AMPARs play crucial roles in the maintenance of basal synaptic transmission and LTD expression, respectively (Chung et al., 2000; Kim et al., 2001), we tested whether the AMPARmediated basal field potential response and LTD are altered by prenatal cocaine exposure. The magnitude of AMPARmediated LTD in the presence of $\mathrm{GABA}_{\mathrm{A}} \mathrm{R}$ blockade by picrotoxin was compared in the mPFC from P2 1 to P25 prenatal saline- and cocaine-exposed rats. The experiment illustrated in Figure $2 a-d$ compared the amplitude of the earliest negative

C

e b
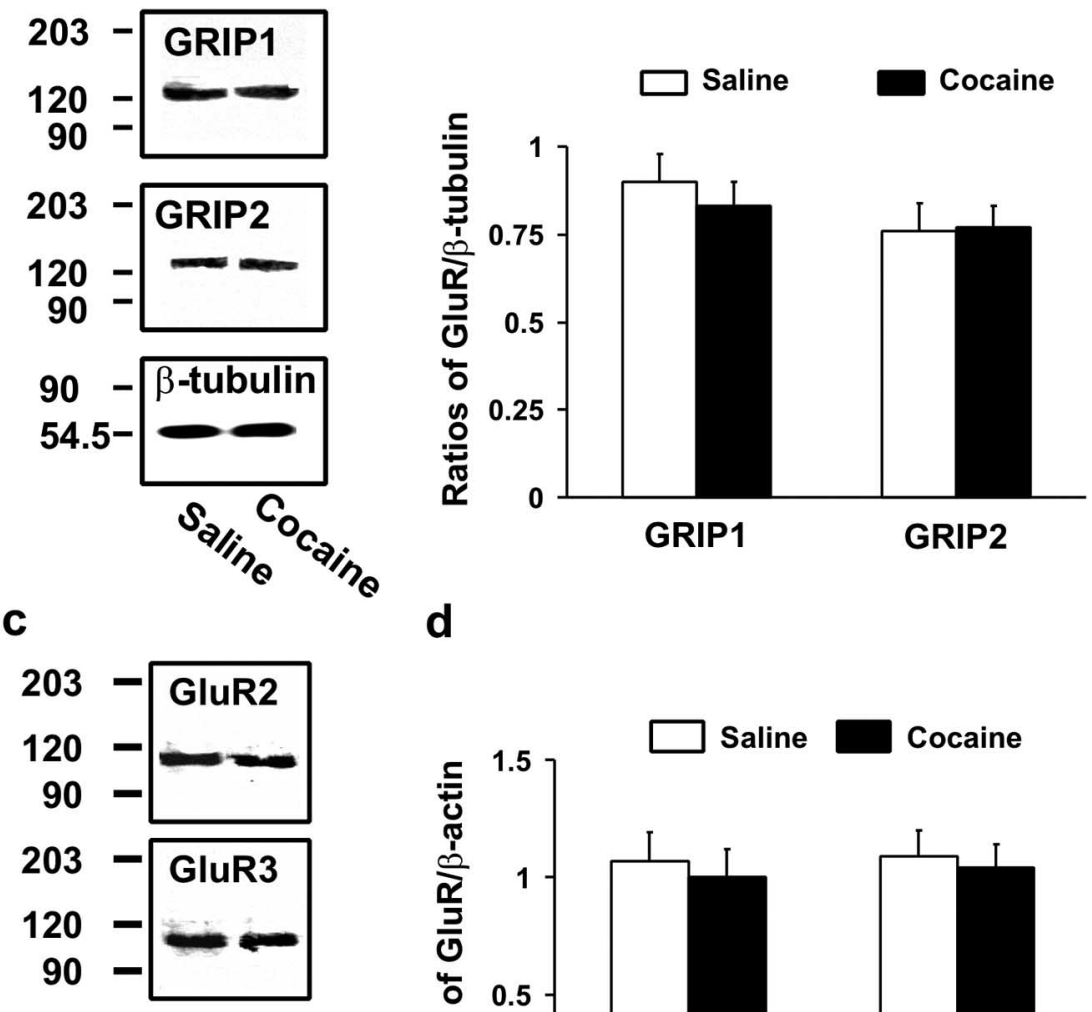

d
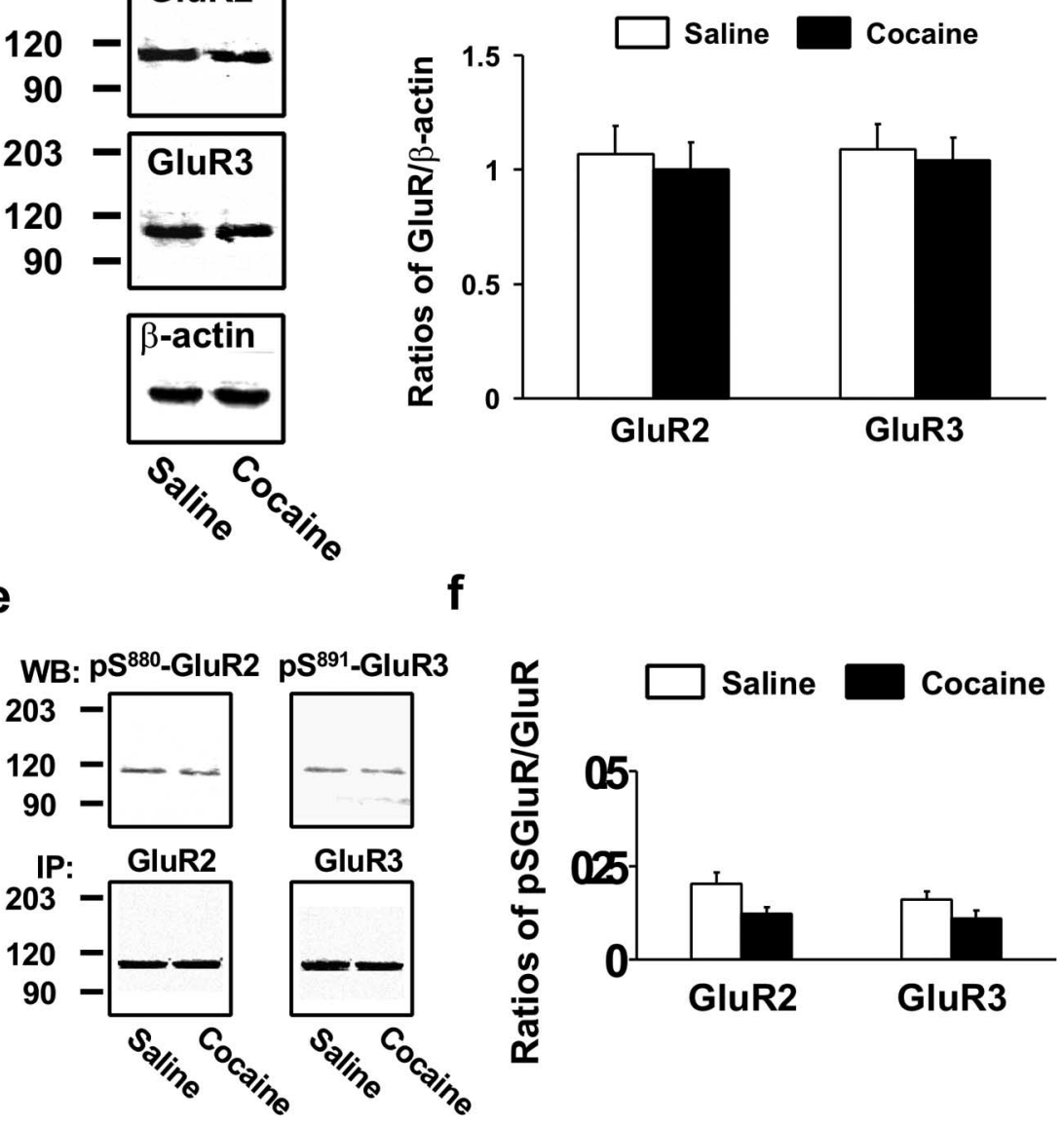

Figure 3. Prenatal cocaine exposure did not alter the expression levels of GRIP1 or GRIP2, GluR2 or GluR3 or pS ${ }^{880}$-GluR2 or $p S^{891}$-GluR3 $(\boldsymbol{a}, \boldsymbol{c}, \boldsymbol{e})$. The expression levels of GRIP1, GRIP2, GluR2, GluR3, ps ${ }^{880}$-GluR2 and ps ${ }^{891}$-GluR3 in postmitochondrial synaptosome-enriched fraction prepared from frontal cortices of $P 21$ rats exposed to saline or cocaine in utero were compared by Western blotting either directly $(\boldsymbol{a}, \boldsymbol{c})$ or after immunoprecipitation with anti-GluR2 or anti-GluR3 $(\boldsymbol{e})$. The blots were stripped and sequentially reprobed with anti- $\beta$-tubulin (a), anti- $\beta$-actin (c), or anti-GluR2 and anti-GluR3 (e) to validate equal loading and/or immunoprecipitation efficiency. Protein bands were quantified and normalized with respect to signals of loading controls $(\boldsymbol{b}, \boldsymbol{d}, \boldsymbol{f})$. Betweengroup differences were not statistically significant $(\boldsymbol{b}, \boldsymbol{d}, \boldsymbol{f})$. Data are presented as means \pm SEM. $n=4$ for each group.

wave (arrowhead) in the evoked field potential before and after LFS. In separate tests, this early wave was blocked by an AMPARselective antagonist CNQX (Fig. 2e). Figure 2 showed that LFS generated a discernibly milder LTD of the AMPAR response in 
a

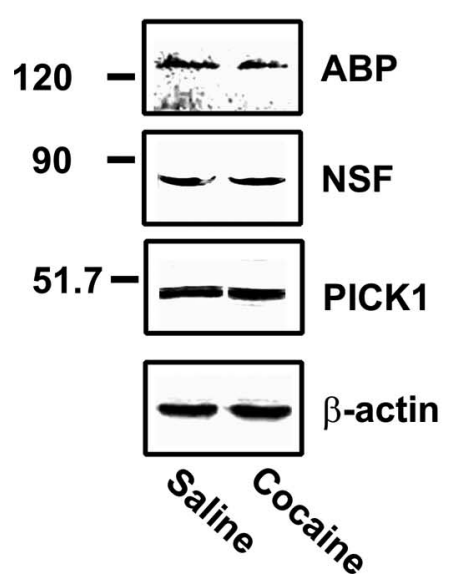

b

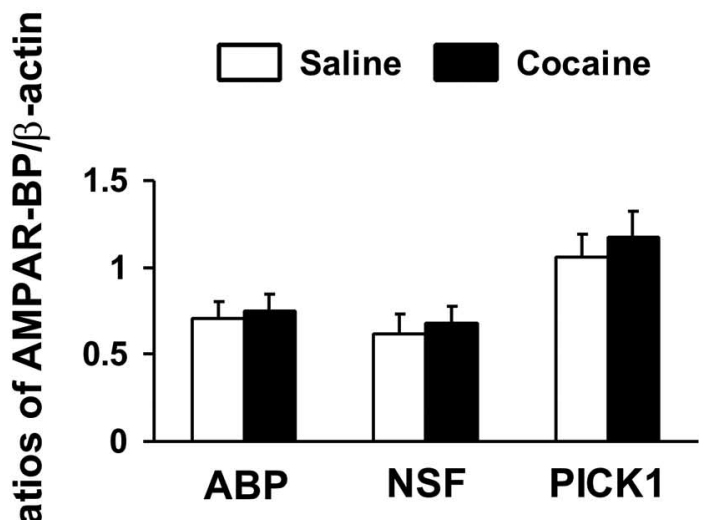

Figure 4. Prenatal cocaine exposure did not alter expression levels of ABP, NSF, and PICK1. Expression levels of ABP, NSF, and PICK1 in postmitochondrial synaptosome-enriched fraction prepared from frontal cortices of $P 21$ rats exposed to saline or cocaine in utero were compared by Western blotting. The blots were stripped and reprobed with anti- $\beta$-actin to validate equal loading. $\boldsymbol{a}$, The blot is a representative of four individual rats from each treatment group. Densitometric quantification of blots shown in $\boldsymbol{b}$; $n=4$. Data are means \pm SEM of the ratios of optical intensity for the indicated protein to loading control, $\beta$-actin $(\boldsymbol{b})$. There were no statistical differences between prenatal saline- and cocaine-exposed rats in these measures.

a

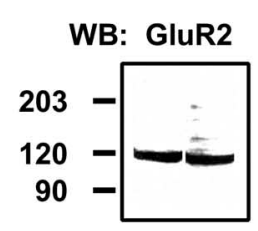

51.7

IP: PICK1

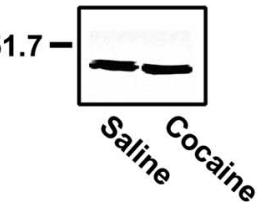

b

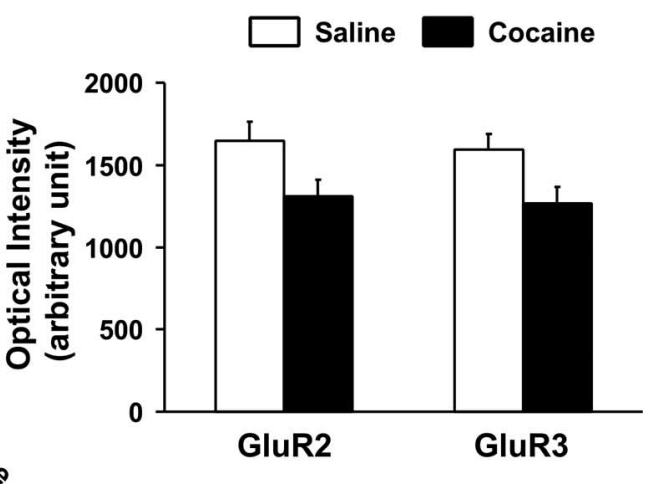

Figure 5. Prenatal cocaine exposure did not alter the association levels of GluR2 or GluR3 with PICK1. $\boldsymbol{a}$, Coupling between GluR2 or GluR3 and synaptic scaffolding protein, PICK1, in the postmitochondrial synaptosome-enriched fraction prepared from frontal cortices of P21 rats exposed to saline or cocaine in utero were compared by Western blotting after immunoprecipitation with anti-PICK1. Blots were stripped and reprobed with anti-PICK1 to validate equal loading and immunoprecipitation efficiency. The blot is a representative of four individual rats from each treatment group $(\boldsymbol{a})$. $\boldsymbol{b}$, Densitometric quantification of four blots identical to that shown in $a$ expressed as means \pm SEM of the ratios of optical intensities for GluR2 or GluR3 to PICK1. $n=4$. There were no statistical differences between prenatal saline- and cocaine-exposed rats in these measures.

the slice from a prenatal cocaine-exposed rat (Fig. $2 a, c)$ than that from a matched prenatal saline-exposed control rat (Fig. $2 b, d)$. Among all the slices tested, $43 \%$ (7 of 16) from prenatal cocaineexposed rats showed significant depression, whereas $73 \%$ (11 of 15) of slices from prenatal saline-exposed rats showed significant depression. In addition, four times more slices in the saline control group showed $>20 \%$ depression (Table 1 ). This reduction in LTD occurred without any discernible change in basal synaptic transmission tested at a large range of stimulus strengths (Table 2, $\sim 1-4 \times$ threshold current). Absence of effect of prenatal cocaine exposure on baseline electrically evoked field potential responses was also confirmed when the magnitude of evoked responses measured as amplitude of the first negativity and as initial slope of the evoked responses both plotted against stimulus current strengths in $\mathrm{mPFC}$ slices from prenatal cocaine- and salineexposed P21 rats (supplemental Fig. 2, available at www.jneuro- sci.org as supplemental material). Similar deficits in LTD also found in MPFC of P21 rats exposed to cocaine during gestation days 8-20 (data not shown).

In a systematic approach to assessing the potential mechanism underlying prenatal cocaine-induced impairment of AMPAR-mediated LTD, we first considered changes in the overall expression of AMPAR GluR2 and GluR3 subunits and their synaptic scaffolding partner GRIP1/2. Because the phosphorylation of GluR2/3 at pSer ${ }^{880}$-GluR2 and pSer ${ }^{891}$-GluR3 by PKC promotes their interaction with PICK1 and subsequent internalization (Chung et al., 2000), we explored the possibility that an altered phosphorylation state of these subunits may have resulted in internalization of GluR2/3 in the prenatal cocaine-exposed brain. However, Western blot data showed that prenatal cocaine exposure did not alter the overall expression of GRIP1 and GRIP2 (Fig. 3a), GluR2 and GluR3 (Fig. 3c), pSer ${ }^{880}$-GluR2 and pSer ${ }^{891}$-GluR3 (Fig. 3e). Prenatal cocaine exposure also did not alter the synaptic levels of scaffolding proteins PICK1, ABP, or the non-PDZ domain containing the AMPAR-interacting protein, NSF (Fig. 4). Since an increased interaction between PICK1 and GluR2/3 could also reduce AMPAR levels on synaptic membrane through enhancing internalization of these AMPAR subunits, we compared the levels of PICK1associated GluR2 and GluR3 in prenatal saline- and cocaine-exposed brains by Western blotting with anti-GluR2 and GluR3 in anti-PICK1 immunoprecipitates. Our data presented in Figure 5 indicate that prenatal cocaine exposure did not affect PICK1-GluR2/3 interaction as similar GluR2 and GluR3 levels were found in PICK1 immunoprecipitates from prenatal cocaine- and salineexposed groups. Together, these data suggest that the apparent retention of GluR2/3 in the cytosol of prenatal cocaine-exposed brains was not the result of altered overall expression of GluR2/3 and synaptic scaffolding molecules, phosphorylated GluR2/3, or their interaction with PICK1.

Prenatal cocaine exposure reduces the interaction between GluR2/3-GRIP

Because GluR2/3 localize in synaptic membranes by interacting with GRIP1/2, we hypothesize that a reduced GluR2/3 interaction with GRIP1/2 in prenatal cocaine-exposed brains may be responsible for the diminished GluR2/3 in synaptic membranes. To directly test this possibility, we first individually isolated native GluR2, GluR3, and GRIP1 from frontal cortices of P21 rats prenatally exposed to saline or cocaine using immunoaffinity columns with immobilized antibodies to each of these proteins. 
a

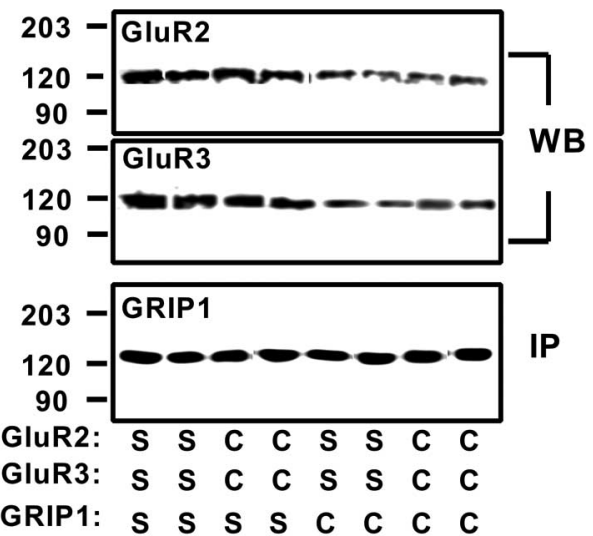

b

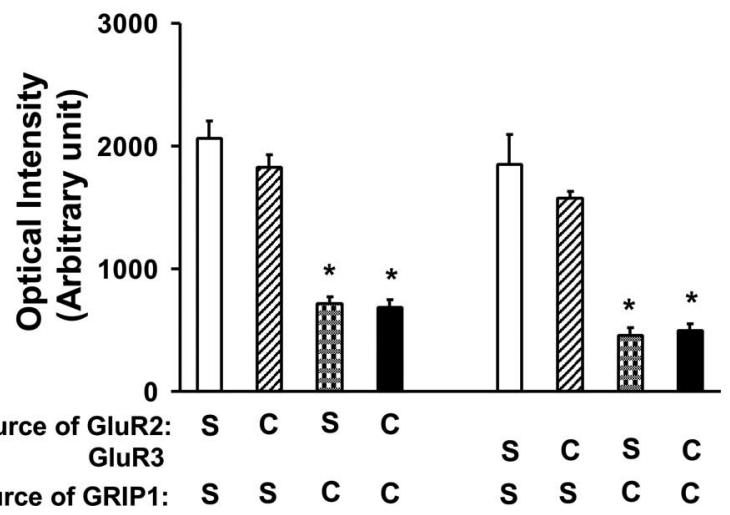

Figure 6. Reduced association between GluR2/GluR3 and GRIP1 in the frontal cortex of prenatal cocaine exposed rats. $\boldsymbol{a}$, Native GRIP1, GluR2, and GluR3 were individually purified from frontal cortices of $\mathrm{P} 21$ rats exposed to saline (S) or cocaine (C) during gestation by immunoaffinity columns with immobilized antibodies in the presence of protease and protein phosphophatase inhibitors. The interaction between GluR2 or GluR3, and GRIP1 was assessed by measuring levels of GluR2 or GluR3 in purified GluR2- or GluR3-GRIP1 complexes using Western blotting. $\boldsymbol{b}$, Densitometric quantification of GluR2 or GluR3 bands. Data are presented as means \pm SEM of optical intensities. $n=4$ for each group. ${ }^{*} p<0.01$ comparing the level of GluR2 or GluR3 in the indicated condition with the group that GRIP1 and receptor are both isolated from prenatal saline-treated rats by Newman-Keuls multiple comparisons that followed one-way ANOVA. No between-group differences were found in GRIP1 level.

To identify the mechanism underlying the prenatal cocaineinduced reduction in synaptic membrane expression of GluR2/3, purified GluR2, GluR3, and GRIP1 in frontal cortices from rats prenatally exposed to saline or cocaine were combined separately in vitro using a cross-over design. After isolation of GRIP1associated GluR2 and GluR3 by coimmunoprecipitation with anti-GRIP1 antibodies, the levels of GluR2 or GluR3 were determined by Western blotting with anti-GluR2 or anti-GluR3 antibodies. The data show that GluR2 and GluR3 isolated from rat brains prenatally exposed either to saline or cocaine bind equally well to GRIP1 from saline-exposed tissues (Fig. $6 a, b$ ). In contrast, the association of GluR2 or GluR3 derived from rats in either treatment group with GRIP1 from prenatal cocaine-exposed rats was markedly reduced (Fig. $6 a, b$ ). These data together indicate that the reduced interaction between GRIP and GluR2/3 in frontal cortices of rats prenatally exposed to cocaine is caused by a persistent modification of the synaptic scaffolding protein GRIP.

PKC- and Src-mediated GRIP1 phosphorylation disrupts GRIP1-GluR2 coupling in the prenatal cocaine-exposed brain Among various potential mechanisms that may change the capability of GRIP to interact with GluR2/3, we considered an altered phosphorylation state of GRIP as the most plausible. GRIP har- a

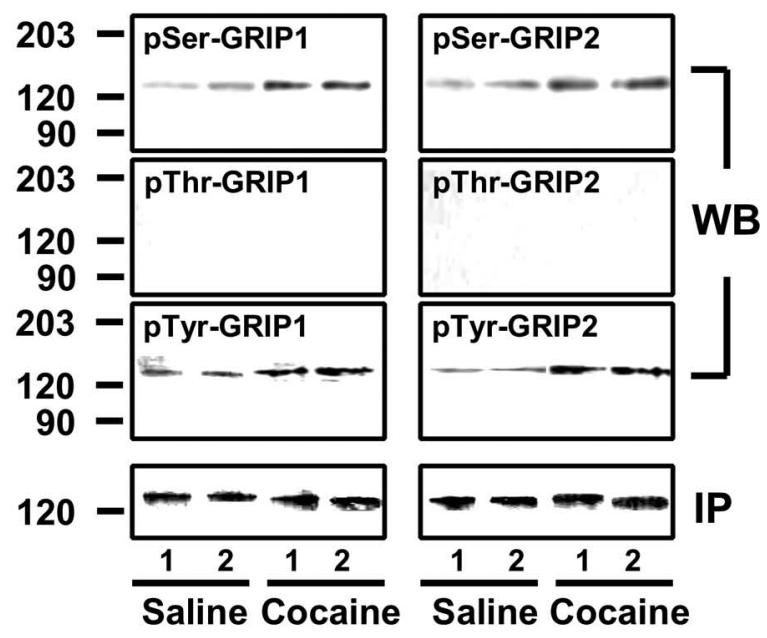

b

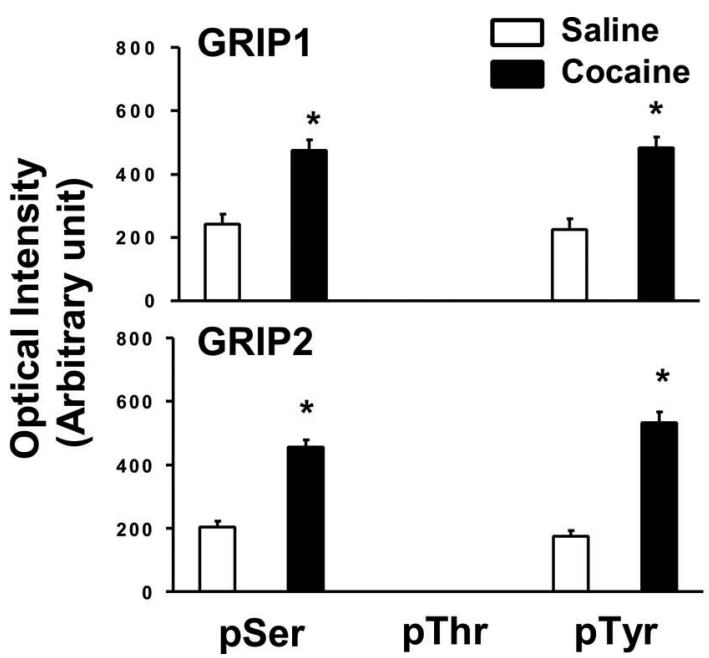

Figure 7. Enhanced serine and tyrosine phosphorylation of GRIP1 and GRIP2 in frontal cortices of prenatal cocaine-exposed rats. $\boldsymbol{a}$, Levels of Serine (Ser), Threonine (Thr), and tyrosine (Tyr) phosphorylation on purified native GRIP1 or GRIP2 from prenatal saline- and cocaineexposed P21 rats were determined by Western blot using specific antibodies directed against each phosphoepitope. $\boldsymbol{b}$, Densitometric quantification of blots. Data are represented as means \pm SEM of the optical intensity. $n=4$ for each group. ${ }^{*} p<0.01$ comparing the levels of phosphorylated GRIP1 and GRIP2 isolated from prenatal saline-treated rats by two-tailed Student's $t$ test. No between-group differences in the levels of GRIP1 immunoprecipitates were detected.

bors putative phosphorylation sites for PKC and other kinases. To investigate how an altered phosphorylation state of GRIP may influence its capacity to anchor with GluR2/3, we compared the phosphorylation states of GRIP using purified native GRIP from frontal cortices of $\mathrm{P} 21$ rats prenatally exposed to saline or cocaine. Using Western blotting with phosphoepitope-specific antibodies, we found that both GRIP1 and GRIP2 derived from prenatal cocaine-exposed rats showed at least a twofold increase in serine (pSer) and tyrosine (pTyr) residues without signs of threonine (pThr) phosphorylation (Fig. 7a,b). Similarly, exposure to cocaine during gestation days 8-20 also increased serine and tyrosine phosphorylation on GRIP1 (supplemental Fig. 2, available at www.jneurosci.org as supplemental material). To further assess whether an increased pSer- and pTyr-GRIP is responsible for the reduced GluR2/3-GRIP interaction in prenatal cocaineexposed brain, we manipulated in vitro the phosphorylation state of the purified GRIP1 from prenatal cocaine- or saline-exposed 


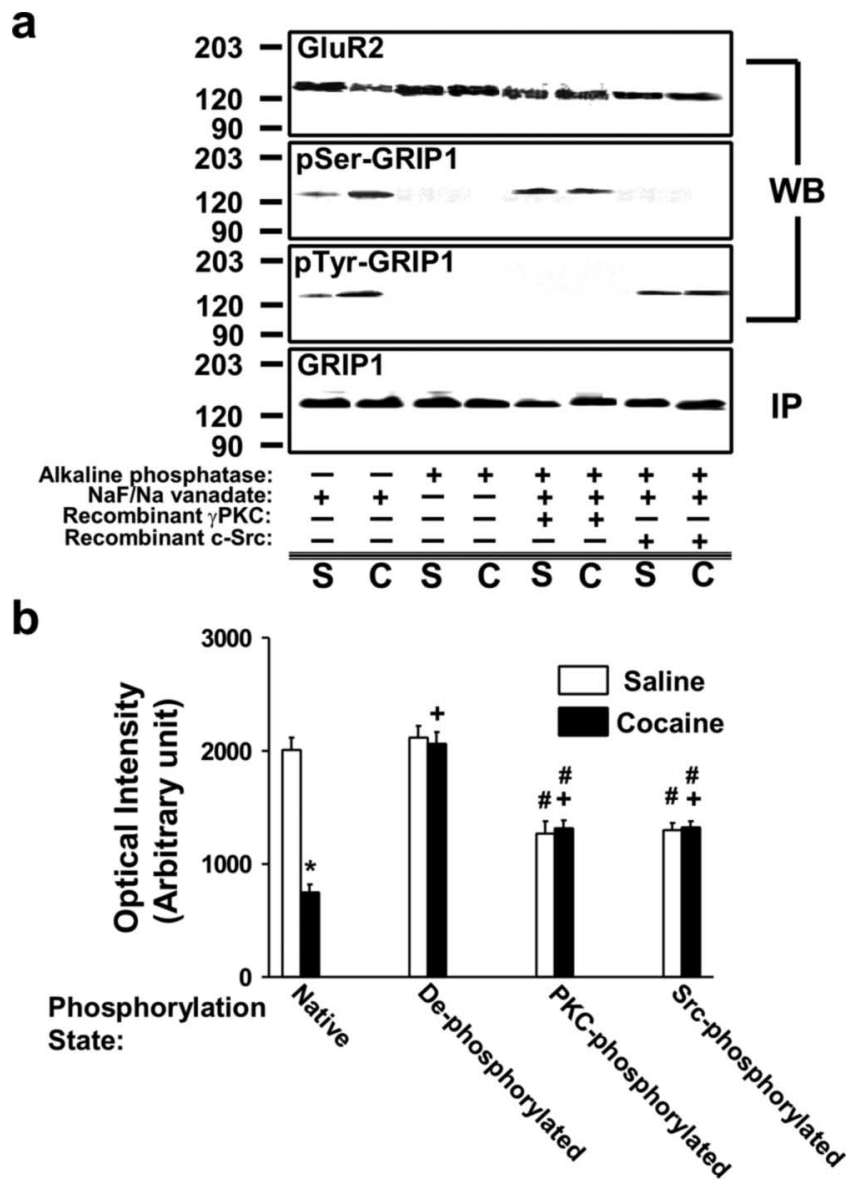

Figure 8. PKC- and Src-mediated phosphorylation of GRIP1 reduces GluR2-GRIP1 coupling in prenatal cocaine-exposed P21 rats. $\boldsymbol{a}$, Immunoaffinity-purified native GRIP1 from frontal cortices of either prenatal saline (S)- or cocaine (C)-exposed rats was treated with vehicle or 100 $\mu \mathrm{g} / \mathrm{ml}$ alkaline phosphatase. After completion of dephosphorylation by addition of inhibitors, phosphate-free GRIP1 was phosphorylated by recombinant PKC or Src in the presence of ATP. The reaction was terminated by specific PKC or Src inhibitors, and GRIP1 was analyzed for phosphoserine and phosphotyrosine by Western blotting. The interaction between GluR2 and GRIP1 with different phosphorylation states was assessed in vitro by incubation of purified GluR2 derived from either prenatal saline- or cocaine-exposed rats with purified, phosphorylated GRIP1. GluR2-GRIP1 complexes were isolated along with GRIP1 by immunoprecipitation, and levels of GluR2 associated with GRIP1 were determined by Western blotting. $\boldsymbol{b}$, Densitometric quantification of the top blot shown in $a . n=4$ for each group. Data are means \pm SEM of the optical intensity. The statistical significance was evaluated by Newman-Keuls multiple comparisons that followed one-way ANOVA. ${ }^{*} p<0.01$ comparing to native GRIP1 from salinetreated group. ${ }^{\#} p<0.01$ comparing with dephosphorylated GRIP from both saline- and cocaine-treated groups. ${ }^{+} p<0.01$ comparing with native GRIP1 from cocaine-treated group.

rats and determined the resulting level of GluR2-GRIP1 association. Dephosphorylation of GRIP by alkaline phosphatase treatment restored the capacity of GRIP1 from prenatal cocaineexposed brains to interact with GluR2 (Fig. 8a,b). Incubation of completely de-phosphorylated GRIP1 from either saline- or cocaine-exposed tissues with activated recombinant PKC or Src significantly reduced the level of GluR2-GRIP1 interaction (Fig. $8 a, b)$. Last, since PKC activation has been shown to activate Src (Brandt et al., 2003) and since increased PKC translocation and activation has been demonstrated in rabbit brain after prenatal cocaine exposure (Wang et al., 1993), we assessed the activation of PKC. We found that levels of synaptic membrane-associated typical and atypical PKC isozymes in frontal cortices of prenatal cocaine-exposed rats were much higher than in frontal cortices of saline controls (Fig. 9a,b). In addition, substantially higher asso- ciation between GRIP1 and activated PKC- $\gamma$, PKC- $\alpha$, and PKC- $\zeta$ as well as $\mathrm{PKM} \zeta$ were noted in frontal cortices from $\mathrm{P} 21$ prenatal cocaine-exposed rats (Fig. 9c,d). Collectively, these data demonstrate that prenatal cocaine exposure promotes PKC translocation and activation leading to increase in GRIP-PKC association and eventual PKC- and Src-mediated phosphorylation of GRIP on serine and tyrosine residues. This PKC- and Src-mediated GRIP phosphorylation, in turn, reduces the capacity of GRIP to interact with GluR2/3.

\section{Discussion}

Studies in both humans and animal models indicate that prenatal cocaine exposure can cause impairment in attention, motor, and language skills, as well as associative and discrimination learning, all of which involve excitatory synapses (Mayes et al., 1995; Romano and Harvey, 1996; Delaney-Black et al., 1996; Bandstra et al., 2002). These findings suggest that exposure to cocaine during early development can modify synaptic plasticity at the excitatory synapses resulting in enduring changes in brain function. In support of this possibility, our data indicate that in utero cocaine exposure attenuates AMPAR-mediated LTD without affecting basal transmission. The reduced AMPAR-LTD in prenatal cocaine-exposed brain is accompanied by reduced AMPARs in synaptic membranes (with apparent retention of GluR2/3 in cytosol), resulting from disrupted GluR2/3-GRIP interaction. This finding concurs with previous demonstrations that disruption of AMPAR constitutive cycling occludes LTD in hippocampal slices (Lüthi et al., 1999; Lüscher et al., 1999). Also resonating with our work showing that prenatal cocaine appears to attenuate AMPAR-mediated LTD without affecting basal transmission is the finding that prevention of GluR2 from binding to PDZ domain in anterior cingulate cortical slices blocks LTD without affecting basal synaptic transmission (Toyoda et al., 2007). Alternatively, the reduced LTD with decreased AMPARs in synaptic membranes observed here may be caused by defective metabotropic glutamate receptor (mGluR)1 signaling in prenatal cocaine-exposed brains (data not shown), since selective blockade of hippocampal mGluR1 reduces LTD expression and decreases AMPAR surface expression (Volk et al., 2006). The reduced AMPAR-LTD with normal basal transmission in prenatal cocaine-exposed brain may suggest that while the lower AMPARs in synaptic membranes are able to sustain basal synaptic activity, the reduced synaptic expression and/or a defective downstream mechanism underlying LTD lead to failure in LTD induction. The attenuated LTD in prenatal cocaine-exposed brains, however, is not likely the result of cocaine withdrawal, since $21 \mathrm{~d}$ of abstinence increases the surface to intracellular ratio of AMPARs (Boudreau and Wolf, 2005; Boudreau et al., 2007; Kourrich et al., 2007). With increasing evidence implicating LTD, especially in the NAc, as a pivotal mediator of drug-induced neuronal plasticity associated with drug addiction (for review, see Brebner et al., 2006), the impaired AMPAR-mediated LTD found in the prenatal cocaine-exposed brain may contribute to cognitive deficits in subjects exposed to cocaine in utero.

The involvement of AMPARs in reward processing has been well documented in adult animals exposed to cocaine (Sutton et al., 2003; Suto et al., 2004; Boudreau and Wolf, 2005; Mead et al., 2007; Conrad et al., 2008; Torregrossa et al., 2008; Famous et al., 2008). An increased AMPARs surface expression in NAc noted in cocaine-sensitized rats $21 \mathrm{~d}$ after last injection suggest that the elevated AMPARs in synapses enable drug-seeking responses (Boudreau and Wolf, 2005). In contrast, pharmacological inhibition of AMPARs (Kaddis et al., 1995; Bäckström and Hyytiä, 
a
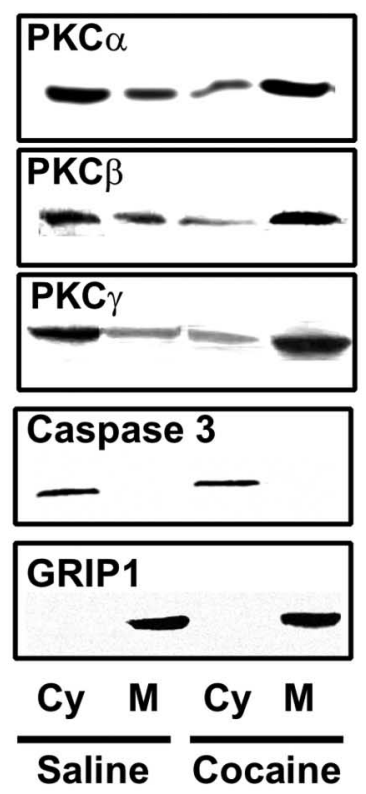

C
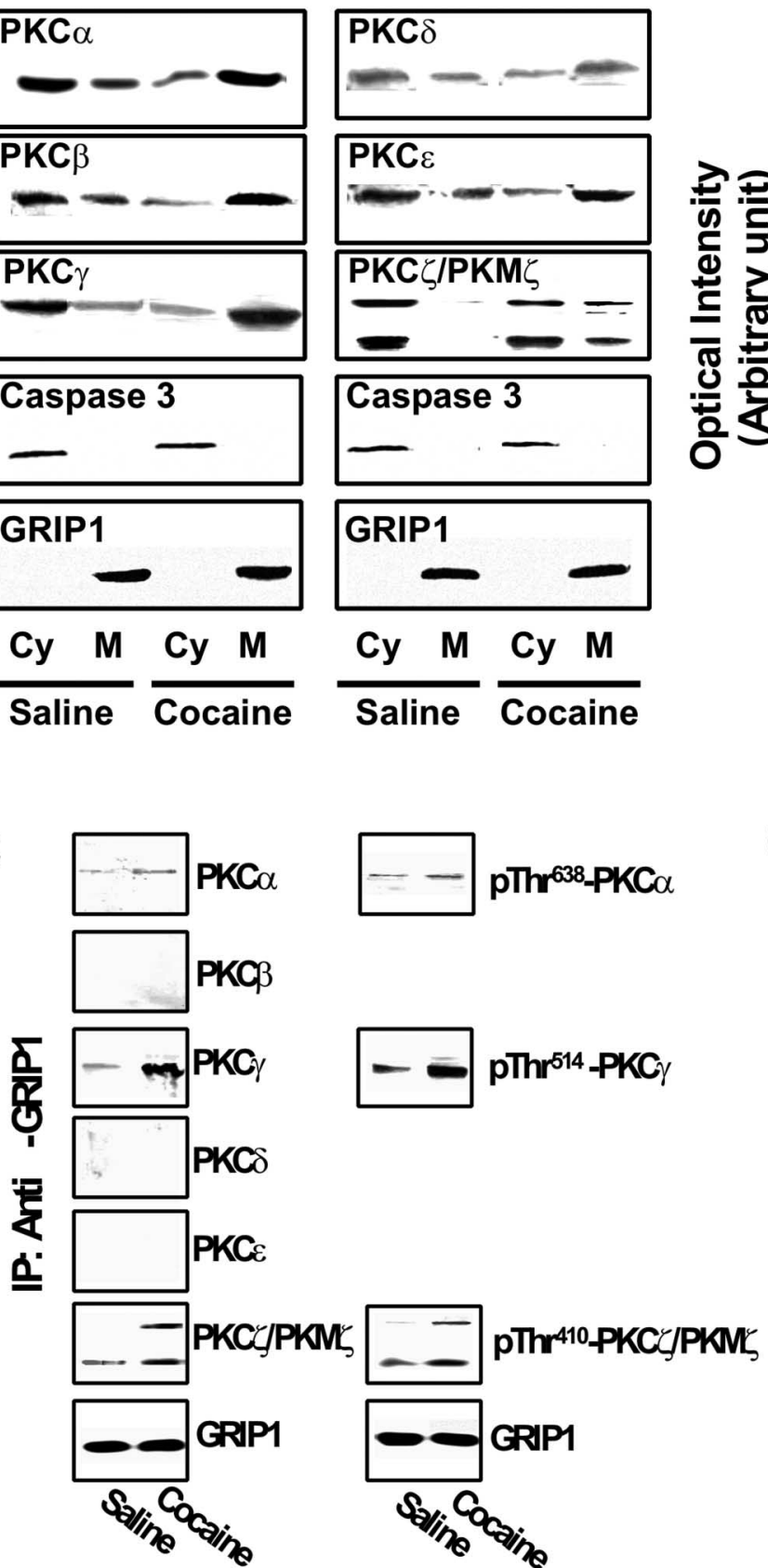
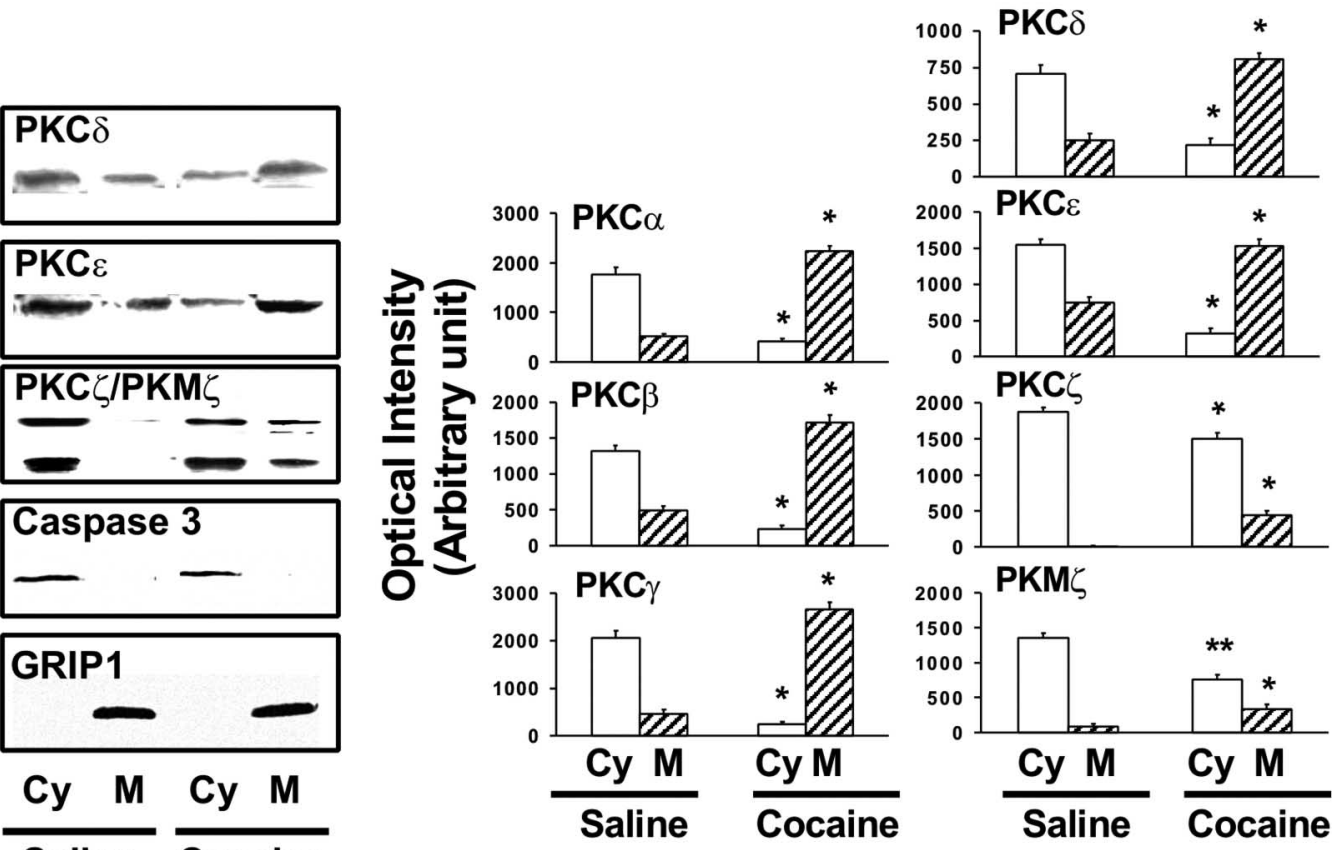

d

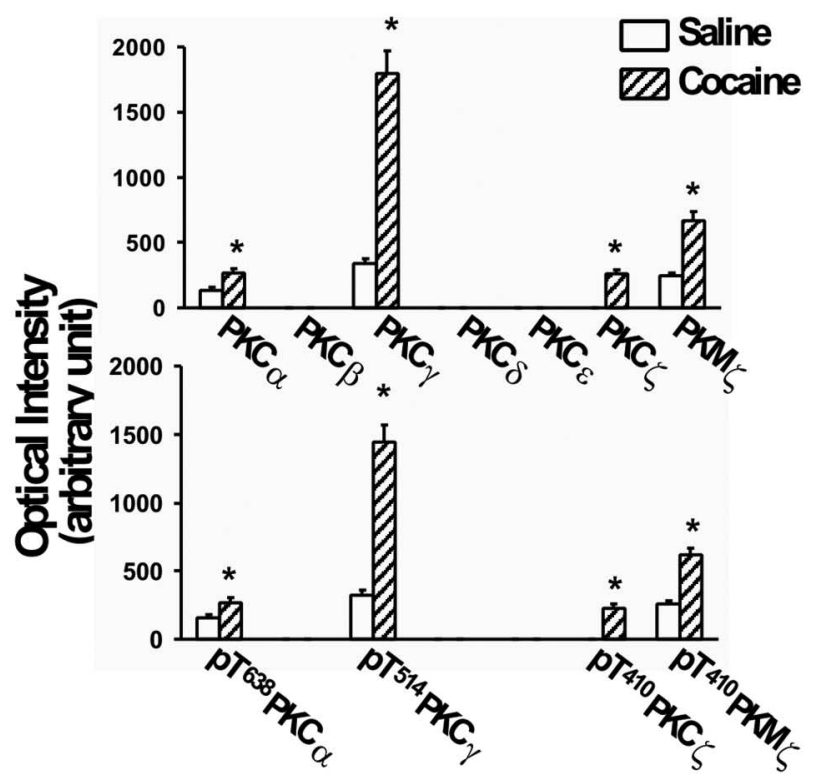

Figure 9. Increased activated PKC- $\alpha$, PKC- $\gamma$, and PKC/PKM- $\zeta$ association with GRIP1 in neuronal membranes from the frontal cortex of prenatal cocaine-exposed rats. $\boldsymbol{a}$, Western blot analysis of the PKC isozyme distribution in the cytosol (Cy) and membrane (M) fractions of synaptosomes prepared from frontal cortices of P21 rats exposed to saline or cocaine during gestation. Blots were stripped and sequentially reprobed with anti-caspase-3 (996 \pm 121 and $874 \pm 119$ optical intensity in saline and cocaine, respectively) and GRIP1 (2349 \pm 165 and $2238 \pm 151$ optical intensity in saline and cocaine, respectively) to validate equal loading in cytosol and membrane extracts. $\boldsymbol{b}$, Densitometric quantification of blots. $\boldsymbol{c}$, Western blot analysis of the overall and activated PKC/M isozymes associated with GRIP1 in neuronal membranes from prenatal saline- and cocaine-exposed P21 rats. $\boldsymbol{d}$, Densitometric quantification of blots. $n=4$ for each group. Data are presented as means \pm SEM of the optical intensities. ${ }^{*} p<0.01$ comparing the level of the indicated PKC isozyme in respective cytosol and membrane fractions assessed by the two-tailed Student's $t$ test.

2003; Harris and Aston-Jones, 2003; Choi et al., 2005; Torregrossa et al., 2008) or GluR1 and GluR2 knockdown (Dong et al., 2004; Mead et al., 2005) attenuates reward by brain stimulation, cocaine, or food. Additionally, studies have shown that rabbits exposed to cocaine in utero are tolerant to cocaine-induced motor sensitization, considered a behavioral correlate of addic- tive processes (Stanwood and Levitt, 2003; Thompson et al., 2005). Our data showing reduced synaptic surface GluR2, GluR3 (Fig. 3), and GluR1 (data not shown) in prenatal cocaine-exposed brains concurs with these findings, implicating reduced AMPAR synaptic membrane localization and LTD expression in the impaired reward processing and tolerance to addictive drugs that 
occur in the offspring of maternal cocaine users. The impairments in food reward in GluR2-deficient mice may also imply that subjects exposed to cocaine during gestation may be at greater risk of depression (Mead et al., 2005). In agreement with this depression-prone hypothesis, prenatal cocaine-exposed rats are significantly more immobile in the forced-swim test at 2 and 4 months of age (Overstreet et al., 2000).

The reduced GluR2/3 in synaptic membranes observed in prenatal cocaine-exposed brain is caused by an attenuated interaction between GluR2/3 and GRIP, the AMPAR synaptic anchoring protein, and not by altered expression of GluR2, GluR3, GRIP1, or GRIP2 or by increased internalization resulting from enhanced pSerGluR2/3-PICK interaction. Incidentally, we have observed fewer GluR1s in the synaptic membranes of prenatal cocaine-exposed brains (data not shown). Hence, a profound reduction in the synaptic membrane localization of AMPARs observed in prenatal cocaine-exposed brain coupled with an attenuated AMPAR-mediated LTD likely contributes to the cognitive changes, including impaired reward processing, exhibited by subjects exposed to cocaine during gestation.

Our data indicate that the reduced GluR2/3-GRIP interaction in prenatal cocaine-exposed brains is the result of a sustained PKC- and Src-mediated phosphorylation of GRIP, the synaptic anchoring protein for GluR2- and GluR3-containing AMPARs. This observation is reminiscent of a previous report that an increased phosphorylation of $\mathrm{D}_{1 \mathrm{~A}}$ dopamine receptors in prenatal cocaine-exposed rabbits results in uncoupling of $\mathrm{D}_{1 \mathrm{~A}}$ dopamine receptors from their signal transducer, $G_{s}$ and $G_{\text {olf }}$ proteins (Zhen et al., 2001). A sustained PKC activation indicated by an overwhelming presence of synaptic membrane-associated multiple $\mathrm{PKC}$ isoforms and a markedly reduced phorbol ester-induced PKC translocation have also been observed in adult rabbit brains exposed to cocaine in utero (Wang et al., 1993). Similarly, we show here that prenatal cocaine treatment throughout gestation promotes cytosol-to-membrane translocation and activation of PKC together with markedly increased association of GRIP with activated PKC- $\alpha$, PKC- $\gamma$ and PKC- $\zeta$ as well as PKM $\zeta$. Since PKC is known to activate Src (Brandt et al., 2003), our data supports the notion that prenatal cocaine exposure hyper-activates PKC, resulting in persistent $\mathrm{PKC}$ - and Src-mediated phosphorylation of GRIP, which in turn prevents GRIP from interacting with GluR2-, GluR3-containing AMPARs. In keeping with our theory that PKC hyperactivation profoundly affects cognitive processing in prenatal cocaine-exposed individuals, excessive PKC activation was found to markedly impair prefrontal cortex-mediated cognitive functions and increase distractibility (Birnbaum et al., 2004). Future experiments are needed to determine whether the reduced synaptic targeting of GluR2- and GluR3-containing AMPARs that we observed in brains from P21 prenatal cocaineexposed rats is persistent or simply a transient shift in synaptic plasticity during early development. Nevertheless, previous studies conducted by us and others in rabbit indicate that such synaptic plasticity changes are long lasting, well into adulthood (Wang et al., 1993; Romano and Harvey, 1996; Stanwood and Levitt, 2003).

In addition to anchoring AMPARs to synaptic membranes, GRIP also interacts with other signaling molecules including GRIP-associated protein 1 (GRASP-1) (Ye et al., 2000), liprin- $\alpha$ (Wyszynski et al., 2002), ephrin B receptors (Hoogenraad et al., 2005), and matrix metalloproteinase 5 (Monea et al., 2006). Although the precise mechanism through which GRIP-interactingsignaling molecules contribute to the reduced GluR2/3 synaptic membrane localization in prenatal cocaine-exposed brain re- mains ambiguous, a previous demonstration that overexpression of GRASP-1 in cultured hippocampal neurons reduces AMPAR synaptic targeting suggests that an overly active or abundant GRASP-1 may be a likely mediator (Ye et al., 2000).

Prenatal cocaine exposure has also been shown to affect numerous neurotransmitter systems including dopamine $\mathrm{D}_{1}$ receptor $-\mathrm{G}_{\mathrm{s} / \mathrm{olf}}$ coupling (H. Y. Wang et al., 1995; Friedman et al., 1996; Jones et al., 2000; Zhen et al., 2001), GABAergic neurons (X. H. Wang et al., 1995), and noradrenergic system (Booze et al., 2006). Defective $D_{1}$ receptor signaling may itself contribute to the reduced AMPAR synaptic membrane localization, since $\mathrm{D}_{1}$ receptor stimulation recruits AMPARs to synaptic membranes (Mangiavacchi and Wolf, 2004). Despite these numerous changes reported to occur in prenatal cocaine-exposed brains, we propose that hyper-activation of PKC resulting in sustained phosphorylation of GRIPs and reduced GluR2/3 synaptic membrane targeting elucidated here may be a prominent cascade of events underlying prenatal cocaine-induced cognitive impairment. Moreover, our data suggest that blocking excessive PKC translocation, a primary $\mathrm{PKC}$ activation mechanism, may be effective in preventing prenatal cocaine from promoting protracted deficits in AMPAR-regulated neurotransmission. Although mood stabilizers such as lithium and valproate may have potential therapeutic value as they block PKC translocation without interfering with the enzymatic activity (Hahn et al., 2005), lithium has also been shown to reduce AMPAR GluR1 and GluR2 synaptic expression (Du et al., 2003; Gray et al., 2003). Hence, among currently marketed drugs, treatments combining mood stabilizers that block PKC activation (Hahn et al., 2005) and antidepressants shown to boost AMPAR levels in synapses may have utility in maintaining proper AMPAR-regulated synaptic activities after prenatal cocaine exposure.

\section{References}

Bäckström P, Hyytiä P (2003) Attenuation of cocaine-seeking behaviour by the AMPA/kainate receptor antagonist CNQX in rats. Psychopharmacology (Berl) 166:69-76.

Bandstra ES, Morrow CE, Vogel AL, Fifer RC, Ofir AY, Dausa AT, Xue L, Anthony JC (2002) Longitudinal influence of prenatal cocaine exposure on child language functioning. Neurotoxicol Teratol 24:297-308.

Birnbaum SG, Yuan PX, Wang M, Vijayraghavan S, Bloom AK, Davis DJ, Gobeske KT, Sweatt JD, Manji HK, Arnsten AF (2004) Protein kinase C overactivity impairs prefrontal cortical regulation of working memory. Science 306:882-884.

Booze RM, Wallace DR, Silvers JM, Strupp BJ, Snow DM, Mactutus CF (2006) Prenatal cocaine exposure alters alpha2 receptor expression in adolescent rats. BMC Neurosci 7:33.

Boudreau AC, Wolf ME (2005) Behavioral sensitization to cocaine is associated with increased AMPA receptor surface expression in the nucleus accumbens. J Neurosci 25:9144-9151.

Boudreau AC, Reimers JM, Milovanovic M, Wolf ME (2007) Cell surface AMPA receptors in the rat nucleus accumbens increase during cocaine withdrawal but internalize after cocaine challenge in association with altered activation of mitogen-activated protein kinases. J Neurosci 27:10621-10635.

Brandt DT, Goerke A, Heuer M, Gimona M, Leitges M, Kremmer E, Lammers R, Haller H, Mischak H (2003) Protein kinase C delta induces Src kinase activity via activation of the protein tyrosine phosphatase PTP alpha. J Biol Chem 278:34073-34078.

Brebner K, Phillips AG, Wang Y-T, Wong TP (2006) Interference peptides: a novel therapeutic approach targeting synaptic plasticity in drug addiction. In: Molecular mechanisms of synaptogenesis (Dityatev A, ElHusseini A eds), pp 473-484. New York: Springer.

Bredt DS, Nicoll RA (2003) AMPA receptor trafficking at excitatory synapses. Neuron 40:361-379.

Choi KH, Clements RL, Greenshaw AJ (2005) Simultaneous AMPA/kainite receptor blockade and dopamine $\mathrm{D}(2 / 3)$ receptor stimulation in the nu- 
cleus accumbens decreases brain stimulation reward in rats. Behav Brain Res 158:79-88.

Chung HJ, Xia J, Scannevin RH, Zhang X, Huganir RL (2000) Phosphorylation of AMPA receptor subunit GluR2 differentially regulates its interaction with PDZ domain-containing proteins. J Neurosci 20:7258-7267.

Conrad KL, Tseng KY, Uejima JL, Reimers JM, Heng LJ, Shaham Y, Marinelli M, Wolf ME (2008) Formation of accumbens GluR2-lacking AMPA receptors mediates incubation of cocaine craving. Nature 454:118-121.

Delaney-Black V, Covington C, Ostrea E Jr, Romero A, Baker D, Tagle MT, Nordstrom-Klee B, Silvestre MA, Angelilli ML, Hack C, Long J (1996) Prenatal cocaine and neonatal outcome: evaluation of dose-response relationship. Pediatrics 98:735-740.

Dong H, O’Brien RJ, Fung ET, Lanahan AA, Worley PF, Huganir RL (1997) GRIP: a synaptic PDZ domain-containing protein that interacts with AMPA receptors. Nature 386:279-284.

Dong Y, Saal D, Thomas M, Faust R, Bonci A, Robinson T, Malenka RC (2004) Cocaine-induced potentiation of synaptic strength in dopamine neurons: Behavioral correlates in GluRA(-/-) mice. Proc Natl Acad Sci U S A 101:14282-14287.

Du J, Gray NA, Falke C, Yuan P, Szabo S, Manji HK (2003) Structurally dissimilar antimanic agents modulate synaptic plasticity by regulating AMPA glutamate receptor subunit GluR1 synaptic expression. Ann N Y Acad Sci 1003:378-380.

Famous KR, Kumaresan V, Sadri-Vakili G, Schmidt HD, Mierke DF, Cha JH, Pierce RC (2008) Phosphorylation-dependent trafficking of GluR2containing AMPA receptors in the nucleus accumbens plays a critical role in the reinstatement of cocaine seeking. J Neurosci 28:11061-11070.

Friedman E, Yadin E, Wang HY (1996) Effect of prenatal cocaine on dopamine receptor-G protein coupling in mesocortical regions of the rabbit brain. Neuroscience 70:739-747.

Gray NA, Du J, Falke CS, Yuan P, Manji HK (2003) Lithium regulates total and synaptic expression of the AMPA glutamate receptor GluR2 in vitro and in vivo. Ann N Y Acad Sci 1003:402-404.

Hahn CG, Umapathy, Wang HY, Koneru R, Levinson DF, Friedman E (2005) Lithium and valproic acid treatments reduce PKC activation and receptor-G protein coupling in platelets of bipolar manic patients. J Psychiatr Res 39:355-363.

Harris GC, Aston-Jones G (2003) Critical role for ventral tegmental glutamate in preference for a cocaine-conditioned environment. Neuropsychopharmacology 28:73-76.

Hollmann M, Heinemann S (1994) Cloned glutamate receptors. Annu Rev Neurosci 17:31-108.

Hoogenraad CC, Milstein AD, Ethell IM, Henkemeyer M, Sheng M (2005) GRIP1 controls dendrite morphogenesis by regulating EphB receptor trafficking. Nat Neurosci 8:906-915.

Jones LB, Stanwood GD, Reinoso BS, Washington RA, Wang HY, Friedman $\mathrm{E}$, Levitt $\mathrm{P}$ (2000) In utero cocaine-induced dysfunction of dopamine $\mathrm{D}_{1}$ receptor signaling and abnormal differentiation of cerebral cortical neurons. J Neurosci 20:4606-4614.

Kaddis FG, Uretsky NJ, Wallace LJ (1995) DNQX in the nucleus accumbens inhibits cocaine-induced conditioned place preference. Brain Res 697:76-82.

Kauer JA, Malenka RC (2007) Synaptic plasticity and addiction. Nat Rev Neurosci 8:844-858.

Kim CH, Chung HJ, Lee HK, Huganir RL (2001) Interaction of the AMPA receptor subunit GluR2/3 with PDZ domains regulates hippocampal long-term depression. Proc Natl Acad Sci U S A 98:11725-11730.

Kourrich S, Rothwell PE, Klug JR, Thomas MJ (2007) Cocaine experience controls bidirectional synaptic plasticity in the nucleus accumbens. J Neurosci 27:7921-7928.

Liu SJ, Cull-Candy SG (2002) Activity-dependent change in AMPA receptor properties in cerebellar stellate cells. J Neurosci 22:3881-3889.

Lüscher C, Xia H, Beattie EC, Carroll RC, von Zastrow M, Malenka RC, Nicoll RA (1999) Role of AMPA receptor cycling in synaptic transmission and plasticity. Neuron 24:649-658.

Lüthi A, Chittajallu R, Duprat F, Palmer MJ, Benke TA, Kidd FL, Henley JM, Isaac JT, Collingridge GL (1999) Hippocampal LTD expression involves a pool of AMPARs regulated by the NSF-GluR2 interaction. Neuron 24:389-399.

Malinow R, Mainen ZF, Hayashi Y (2000) LTP mechanisms: from silence to four-lane traffic. Curr Opin Neurobiol 10:352-357.

Mangiavacchi S, Wolf ME (2004) D1 dopamine receptor stimulation in- creases the rate of AMPA receptor insertion onto the surface of cultured nucleus accumbens neurons through a pathway dependent on protein kinase A. J Neurochem 88:1261-1271.

Mayes LC, Bornstein MH, Chawarska K, Granger RH (1995) Information processing and developmental assessments in 3-month-old infants exposed prenatally to cocaine. Pediatrics 95:539-545.

Mead AN, Brown G, Le Merrer J, Stephens DN (2005) Effects of deletion of gria1 or gria2 genes encoding glutamatergic AMPA-receptor subunits on place preference conditioning in mice. Psychopharmacology (Berl) 179:164-171

Mead AN, Zamanillo D, Becker N, Stephens DN (2007) AMPA-receptor GluR1 subunits are involved in the control over behavior by cocainepaired cues. Neuropsychopharmacology 32:343-353.

Monea S, Jordan BA, Srivastava S, DeSouza S, Ziff EB (2006) Membrane localization of membrane type 5 matrix metalloproteinase by AMPA receptor binding protein and cleavage of cadherins. J Neurosci 26:2300-2312.

Morrow CE, Culbertson JL, Accornero VH, Xue L, Anthony JC, Bandstra ES (2006) Learning disabilities and intellectual functioning in school-aged children with prenatal cocaine exposure. Dev Neuropsychol 30:905-931.

Nagele RG, D'Andrea MR, Anderson WJ, Wang HY (2002) Intracellular accumulation of beta-amyloid(1-42) in neurons is facilitated by the alpha 7 nicotinic acetylcholine receptor in Alzheimer's disease. Neuroscience 110:199-211.

Otani S, Blond O, Desce JM, Crépel F (1998) Dopamine facilitates longterm depression of glutamatergic transmission in rat prefrontal cortex. Neuroscience 85:669-676.

Overstreet DH, Moy SS, Lubin DA, Gause LR, Lieberman JA, Johns JM (2000) Enduring effects of prenatal cocaine administration on emotional behavior in rats. Physiol Behav 70:149-156.

Romano AG, Harvey JA (1996) Prenatal exposure to cocaine disrupts discrimination learning in adult rabbits. Pharmacol Biochem Behav 53:617-621.

Saal D, Dong Y, Bonci A, Malenka RC (2003) Drugs of abuse and stress trigger a common synaptic adaptation in dopamine neurons. Neuron 37:577-582.

Shi S, Hayashi Y, Esteban JA, Malinow R (2001) Subunit-specific rules governing AMPA receptor trafficking to synapses in hippocampal pyramidal neurons. Cell 105:331-343.

Srivastava S, Osten P, Vilim FS, Khatri L, Inman G, States B, Daly C, DeSouza S, Abagyan R, Valtschanoff JG, Weinberg RJ, Ziff EB (1998) Novel anchorage of GluR2/3 to the postsynaptic density by the AMPA receptorbinding protein ABP. Neuron 21:581-591.

Stanwood GD, Levitt P (2003) Repeated i.v. cocaine exposure produces long-lasting behavioral sensitization in pregnant adults, but behavioral tolerance in their offspring. Neuroscience 122:579-583.

Suto N, Tanabe LM, Austin JD, Creekmore E, Pham CT, Vezina P (2004) Previous exposure to psychostimulants enhances the reinstatement of cocaine seeking by nucleus accumbens AMPA. Neuropsychopharmacology 29:2149-2159.

Sutton MA, Schmidt EF, Choi KH, Schad CA, Whisler K, Simmons D, Karanian DA, Monteggia LM, Neve RL, Self DW (2003) Extinction-induced upregulation in AMPA receptors reduces cocaine-seeking behavior. Nature 421:70-75.

Thomas MJ, Beurrier C, Bonci A, Malenka RC (2001) Long-term depression in the nucleus accumbens: a neural correlate of behavioral sensitization to cocaine. Nat Neurosci 4:1217-1223.

Thompson BL, Levitt P, Stanwood GD (2005) Prenatal cocaine exposure specifically alters spontaneous alternation behavior. Behav Brain Res 164:107-116.

Torregrossa MM, Tang XC, Kalivas PW (2008) The glutamatergic projection from the prefrontal cortex to the nucleus accumbens core is required for cocaine-induced decreases in ventral pallidal GABA. Neurosci Lett 438:142-145.

Toyoda H, Wu LJ, Zhao MG, Xu H, Jia Z, Zhuo M (2007) Long-term depression requires postsynaptic AMPA GluR2 receptor in adult mouse cingulate cortex. J Cell Physiol 211:336-343.

Turrigiano GG, Nelson SB (2004) Homeostatic plasticity in the developing nervous system. Nat Rev Neurosci 5:97-107.

Ungless MA, Whistler JL, Malenka RC, Bonci A (2001) Single cocaine exposure in vivo induces long-term potentiation in dopamine neurons. Nature 411:583-587. 
Volk LJ, Daly CA, Huber KM (2006) Differential roles for group 1 mGluR subtypes in induction and expression of chemically induced hippocampal long-term depression. J Neurophysiol 95:2427-2438.

Wang HY, Yadin E, Friedman E (1993) Prenatal exposure to cocaine produces sustained subcellular redistribution of protein kinase $\mathrm{C}$ (PKC) Soc Neurosci Abstr 19:757.11.

Wang HY, Yue TL, Feuerstein G, Friedman E (1994) Platelet-activating factor: diminished acetylcholine release from rat brain is mediated by a $\mathrm{G}_{\mathrm{i}}$ protein. J Neurochem 63:1720-1725.

Wang HY, Runyan S, Yadin E, Friedman E (1995) Prenatal exposure to cocaine selectively affects $\mathrm{D}_{1}$ dopamine receptor-mediated activation of striatal Gs proteins. J Pharmacol Exp Ther 273:492-498.

Wang XH, Levitt P, Grayson DR, Murphy EH (1995) Intrauterine cocaine exposure of rabbits: persistent elevation of GABA-immunoreactive neurons in anterior cingulated cortex but not visual cortex. Brain Res 689:32-46.

Wang HY, Wild KD, Shank RP, Lee DH (1999) Galanin inhibits acetylcholine release from rat cerebral cortex via a pertussis toxin-sensitive $G_{i}$ protein. Neuropeptides 33:197-205.

Wenthold RJ, Petralia RS, Blahos J II, Niedzielski AS (1996) Evidence for multiple AMPA receptor complexes in hippocampal CA1/CA2 neurons. J Neurosci 16:1982-1989.
Wolf ME, Sun X, Mangiavacchi S, Chao SZ (2004) Psychomotor stimulants and neuronal plasticity. Neuropharmacology 47 [Suppl 1]:61-79.

Wyszynski M, Kim E, Dunah AW, Passafaro M, Valtschanoff JG, Serra-Pagès C, Streuli M, Weinberg RJ, Sheng M (2002) Interaction between GRIP and liprin-alpha/SYD2 is required for AMPA receptor targeting. Neuron 34:39-52.

Xia J, Zhang X, Staudinger J, Huganir RL (1999) Clustering of AMPA receptors by the synaptic PDZ domain-containing protein PICK1. Neuron 22:179-187.

Yablonsky-Alter E, Gashi E, Lidsky TI, Wang HY, Banerjee SP (2005) Clozapine protection against gestational cocaine-induced neurochemical abnormalities. J Pharmacol Exp Ther 312:297-302.

Ye B, Liao D, Zhang X, Zhang P, Dong H, Huganir RL (2000) GRASP-1: a neuronal RasGEF associated with the AMPA receptor/GRIP complex. Neuron 26:603-617.

Zhen X, Torres C, Wang HY, Friedman E (2001) Prenatal exposure to cocaine disrupts $\mathrm{D}_{1 \mathrm{~A}}$ dopamine receptor function via selective inhibition of protein phosphatase 1 pathway in rabbit frontal cortex. J Neurosci 21:9160-9167.

Zhu JJ, Esteban JA, Hayashi Y, Malinow R (2000) Postnatal synaptic potentiation: delivery of GluR4 containing AMPA receptors by spontaneous activity. Nat Neurosci 3:1098-1106. 